\title{
LA CULTURA POLÍTICA EN EL SEXENIO
}

JOSÉ PEÑA GONZÁLEZ

Catedrático de Derecho Constitucional

Universidad San Pablo-CEU 


\section{SUMARIO}

I. La REALIdAd histórico-política. II. CONCEPTO de Estructura Histórica. III. La Teoría de los Conjuntos Históricos. IV. La Cultura Política. V. La Historia INTEgRal. VI. UNA CUESTIÓN METOdOLOGICA: FUnCIONALISMO Y Estructuralismo. VII. La Teoría de la Revolución. VIII. Memoria histórica Y SITUACIÓN POLITICA. IX. CONCIENCIA DE CRISIS Y ALCANCE DE LA MISMA: a) Crisis del sistema. b) Crisis dinástica. c) Crisis de ideas. d) Crisis de la clase política. e) Crisis social y económica. X. LA CONSTITUCIÓN. XI. LA REALIDAD DEL PODER. XII. CONCLUSIONES. 


\title{
LA CULTURA POLÍTICA EN EL SEXENIO' ${ }^{1}$
}

POR

\author{
JOSÉ PEÑA GONZÁLEZ \\ Catedrático de Derecho Constitucional \\ Universidad San Pablo-CEU
}

El presente trabajo pretende analizar el hecho histórico de la Constitución de 1869 como parte de un proceso que hasta fechas relativamente recientes ha recibido en nuestra historiografia el nombre de Sexenio Revolucionario o Revolución Gloriosa, y que en la actualidad suele encajarse dentro de la denominación Sexenio Democrático².

\section{LA REALIDAD HISTÓRICO-POLÍTICA}

Ello supone en primer lugar analizar el texto jurídico político del 69 desde la propia realidad histórica que lo hizo posible, lo que impli-

1 El tema en extenso en Peña Gonzalez, José: Cultura Politica y Constitución de 1869 (Las Funciones de la Constitución), Centro de Estudios Politicos Y Constitucionales, Madrid, 2002.

2 Ésta es la interpretación, entre otros, de JOVER ZAMORA, quien afirma: “Ha sido corriente calificar como "revolucionario" el sexenio iniciado con la Revolución de Septiembre y terminado con la Restauración; tal calificación se explica por el hecho revolucionario de su iniciación más que por un supuesto carácter revolucionario de su transcurso, en especial desde comienzos de 1874. Por mi parte estimo más adecuado calificarlo de "democrático", teniendo en cuenta tanto su inspiración popular y su ideología preponderante, como la vigencia que en el mismo tuvo nuestra primera Constitución democrática: la de 1869". Vid. La Civilización Española a mediados del siglo XIX, Espasa-Calpe, Madrid, 1991. Nota n.², pág. 19. 
ca un análisis de todas las circunstancias históricas, sociales, culturales y políticas que influyeron en la misma y ver en qué medida resultaron incluidas en su texto. Como afirma Otto Brunner es imposible comprender adecuadamente una constitución al margen de la historia política del país en cuestión ${ }^{3}$. En idéntico sentido se ha manifestado entre nosotros, subrayando aún más el peso específico de la estricta realidad política, el Profesor Tomás Villarroya cuando afirmaba que: «... el jurista que prescinda de la politica llega a resultados vacíos de sentido o, a lo sumo, a un conocimiento del Estado falto de todo aliento vital. Un derecho constitucional separado de la política sería un manojo de formas sin alma, un conjunto de esquema admirable por su compostura y simetría pero totalmente incomprensible ya que, en la mayor parte de los casos, la política ilumina la naturaleza íntima de aquellos principios que luego tienen una consagración y concreción en la letra de la norma positivan 4 .

\section{CONCEPTO DE ESTRUCTURA HISTÓRICA}

Pero dicha realidad histórica es una "estructura histórica» en la que confluyen una serie de elementos que la van configurando ${ }^{5}$. Desde el punto de vista procedimental, la completa visión de una estructura histórica exige obligatoriamente cumplir una serie.de pasos que esquemáticamente pueden ser los siguientes:

3 BRunner, Otto: “El historiador y la Historia de la Constitución y el Derecho", en Revista de las Cortes Generales, n. 11 , Madrid, 1987, pág. 11.

4 Véase su comentario al libro "El Régimen Constitucional Español», vol. I, de Jorge DE EstebAn y otros, en Revista Española de Derecho Constitucional, n. ${ }^{\circ}$ 3, Madrid, 1981, pág. 336.

5 Utilizo la expresión "estructura histórica" en el sentido acuñado por el Profesor MARAVALl CASESNOVES como "construcción mental en que se nos muestra un conjunto de hechos dotados de una interna articulación, en la cual se sistematiza y cobra sentido, la compleja red de relaciones que entre tales hechos se da". Véase su obra La cultura del Barroco, Ed. Ariel, Barcelona, 1975, pág. 18. El concepto de estructura histórica fue introducido por el Profesor MARAVALL como teoría interpretativa de los datos históricos, en sus explicaciones de cátedra de Historia del Pensamiento de la Facultad de Ciencias Políticas y. Económicas de la Universidad Complutense, durante el curso 1955 y siguientes y recogida más tarde en forma sistemática en su Teoría del Saber Histórico, Madrid, 1967. El propio autor recuerda su prioridad cronológica en la utilización de este término, que empieza a ser utilizado entre los historiadores europeos y americanos a partir de 1960, tras las famosas conversaciones de LEVI-StRAUSS ante la radio francesa en 1959. 
1. Situar el «Hecho histórico» en cuestión.

2. Limitarlo temporalmente.

3. Situarlo espacialmente.

4. Conectarlo con situaciones históricas afines.

$5 .^{\circ}$ Dentro de cada "hecho" ver las conexiones entre las partes $y$ el todo.

6. Interpretar el "todo" desde las partes que lo integran.

7. Comprobar hasta qué punto el todo resultante es coherente con las partes que lo integran.

8. Ver si había alguna posibilidad de conseguir un resultado final distinto del todo resultante, o si en cierta medida la solución final venia ya predeterminada.

\section{LA TEORÍA DE LOS CONJUNTOS HISTÓRICOS}

Con base en lo anterior, el hecho histórico del sexenio, entendido como una estructura histórica que permita analizar y conectar las distintas relaciones que se dan dentro de la misma puede ser concebido como un conjunto histórico en el sentido que el profesor Maravall ha dado al término, es decir como una construcción mental de la que se vale el estudioso para encontrar sentido a las múltiples e interdependientes relaciones que ligan unos datos con otros, y que permiten "conocer una realidad histórica, captar su sentido, hacer inteligible la relación entre las partes y el todo" ${ }^{6}$.

Desde este planteamiento, el presente trabajo podría sistematizarse bajo el siguiente esquema:

1. Análisis del Sexenio como un «conjunto histórico».

6 Op. cit., pág. 17. Añade el Profesor Maravall que estos «conjuntos históricos" "son el objeto de la Historia y que todo hecho histórico es por definición un conjunto históricon: No olvida el profesor de Madrid que en la interpretación de estos conjuntos puede caerse en la subjetividad,que deseablemente debe ser la mínima, pero que nunca está totalmente exenta de la labor científica en que el investigador - que tiene que superar su condición de mero documentalista - puede incurrir en su búsqueda de una interpretación cientifica de los hechos o conjuntos históricos que analiza. 
2. Exposición y estudio de todos los variados «hechos históricos" que integran el conjunto.

3. Visión comparada de la estructura histórica del sexenio con las estructuras europeas de la época, conscientes de la existencia de estructuras básicas comunes entre los distintos países y que, como recuerda reiteradamente Jover, la historia española está muy conectada con la europea y que tanto nuestros problemas, como incluso las soluciones, suelen coincidir con las aportadas por nuestros vecinos más de lo que parece a primera vista?

\section{LA CULTURA POLÍTICA}

Con este aparato metodológico pretendemos analizar la Constitución de 1869 como el "hecho histórico" determinante, dentro del "conjunto histórico" que representa el Sexenio ${ }^{8}$. Para adentrarnos en el análisis de ambos términos, vamos a utilizar el concepto de cultura política, entendiendo por ello " el conjunto de actitudes y pautas de comportamiento predominantes en el seno de una determinada sociedad» ${ }^{9}$.

7 La visión de una problemática diferente con una solución también diferente en españa respecto a Europa es una simplificada visión histórica que en la mayor parte de los casos esconde oscuros planteamientos políticos. Resulta curioso el esfuerzo por plantear el "hecho diferencial" de nuestra historia frente a la europea, mientras por los mismos autores se ignora el hecho diferencial dentro de nuestras fronteras.

8 La Constitución de la Gloriosa ha sido comentada desde el punto de vista jurídico por el Profesor Carro Martínez, Antonio, en La Constitución Española de 1869, Ediciones de Cultura Hispánica. Madrid, 1962, 384 págs. Hasta hace muy poco era el único trabajo sistemático y de conjunto que habia sobre la misma. El libro lleva un prólogo de Fraga Iribarne y consta de seis apartados. El último de ellos es una exegesis del articulado de la Constitución. Hoy contamos también con la obra de Antonio LorCA Siero Las Cortes Constituyentes de 1869-1871, Ed. Man, León, 1996. Son dos volúmenes. El primero (358 págs.) se dedica a la Constitución. El segundo (381 págs.) analiza la legislación postconstitucional e incluye la bibliografia utilizada. Por supuesto, aparece tratada en profundidad, dada su importancia, en todos los trabajos y manuales de Historia del Constitucionalismo Histórico Español.

9 Los estudios sobre cultura política tienen como punto de partida la obra de Gabriel ALmond y Sidney Verba The Civic Culture, publicada por la Universidad de Princeton en 1963, y de la que existe edición en español con el título La cultura cívica, Euroamerica, Madrid, 1970. En España el tema de la cultura política como 
La ventaja de este concepto es que permite utilizar tanto los métodos funcionalistas como los estructuralistas a la hora de analizar los hechos históricos. Por otra parte se trata de un concepto suficientemente amplio, que abarca desde la forma de Estado a la de Gobierno, pasando por el análisis del Régimen Político, número y estructura de partidos, libertades y derechos, garantías constitucionales, así como el sistema de valores e ideas dominantes en el seno de una sociedad determinada. Se trataría con ello de comprender por qué la Constitución de 1869, fue lo que fue desde el punto de vista jurídico constitucional, qué efectos tuvo, hasta qué punto representó la cultura política hegemónica o dominante ${ }^{10}$. En el estudio del sistema de valores vigentes en la sociedad de la época habrá que incluir el amplio sentido de cultura aportado por Taylor como "ese todo complejo que abarca conocimientos, ideas religiosas, artes, costumbres, derecho, usos $y$ toda aquella gama de capacidades $y$ actividades fijas que adquiere el individuo como miembro de la socie$\operatorname{dad}^{11}$.

En una línea muy parecida está la definición de cultura en Clifford Geertz cuando afirma: "Creyendo con Max Weber que el hombre

objeto de estudio científico es relativamente reciente, pudiendo situarse su inicio en algunos análisis interpretativos del fenómeno de la Transición política.

La última publicación sobre el tema se titula precisamente Cultura Política y es un conjunto de textos de varios estudiosos del tema, editados por Pilar del Castillo e Ismael Crespo y publicados por la Editorial Tiranch lo Blanch, Valencia, 1997, que inaugura con esta obra su nueva colección de Ciencia Política.

10 El término fue introducido por Gramsci y recogido por Lukacs, Bloch, Adorno y Benjamín.

11 Recogido por Jover en La civilización española a mediados del siglo XIX, Espasa-Calpe. Madrid, 1991, pág. 313. El Profesor JovER recoge esta definición al estudiar la contraposición entre los conceptos de Cultura y Civilización, al estudiar la conexión de la cultura española del XIX con las cultura europea de la época.

La contraposición cultura-civilización es algo más que un planteamiento metodológico. De entrada el término cultura es más afín a la mentalidad germánica y anglosajona que a la latina, que por influencia francesa ha preferido siempre el término civilización. El término cultura (Kultur) ha contado con un fuerte aparato intelectual que lo respalda. Es el caso de Herder, Kant, Goethe, Fichte y Humboldt. Se ha producido también, como ha destacado Julio Caro Baroja, una valoración negativa del término civilización, especialmente a partir de la obra de Spengler, y por la excesiva dependencia que al término civilización se le dio respecto al concepto Progreso. En España a partir de Masdeu empieza a divulgarse el concepto cultura, ya en el siglo XVIII. Véase el término "Cultura" en el Diccionario de Historia de España, Rev. Occidente, vol. I, pág. 1053. Para el término "Civilización», la misma obra, págs. 843 y ss. En ambos casos la autoría corresponde a Julio Caro Baroja. 
es un animal inserto en tramas de significación que él mismo ha tejido, considero que la cultura es esa urdimbre y que el análisis de la cultura ha de ser por lo tanto, no una ciencia experimental en busca de leyes, sino una ciencia interpretativa en busca de significaciones» ${ }^{12}$. Efectivamente, y como recuerda Maria Luz Morán, de eso se trata, de interpretar "diferentes elementos relacionados políticamente: poder, acción, discursos políticos, mitos, símbolos, lenguajes etc.", en tanto en cuanto "la cultura es siempre política en cuanto que trata de la realidad social" $y$ "está compuesta por aquellos significados que están disponibles para hablar, escribir y pensar acerça de los objetos políticos: mitos, metáforas, lenguajes e ideasi ${ }^{13}$. Naturalmente este término de "cultura" hay que entenderlo, como recuerda Scheler, ante todo como "humanización», una humanización que se refiere tanto al proceso que nos hace hombres, como al hecho de que los productos culturales quedan "humanizados», es decir plenamente integrados en la realidad social de la que participamos ${ }^{14}$. Desde este punto de vista, la cultura es el mundo propio del hombre, lo que no significa que éste no participe también del mundo de la naturaleza, siguiendo el esquema diltheiano.

En este contexto, y siguiendo los pasos diseñados por la profesora Morán, se desemboca en una "concepción multidimensional de la relación que se establece entre los cuatro protagonistas de los procesos de construcción de las culturas políticas (elites, medios de comunicación, grupos sociales e individuos|"15.

Dentro de ese concepto de cultura política antes reseñado, ocupa un papel primordial el Derecho, un evidente producto cultural que responde y descansa en los parámetros culturales vigentes en cada sociedad en un momento determinado. Responder jurídicamente a dichos planteamientos es la función del Derecho. Incluirlos en la Constitución como norma fundamental del estado es la misión del Derecho

12 Geertz, C., La interpretación de las culturas, Barcelona, 1990, pág. 20.

13 Morán, María Luz, Cultura Política, Ed. de Pilar del Castillo e Ismael Crespo, Valencia, 1997, pág. 199. Morán reconoce que ésta es la tesis mantenida por Gamson, uno de los más brillantes defensores de los estudios empíricos aplicados a la cultura política.

14 Así lo afirma Ferrater Mora. Véase Diccionario..., tomo l, pág. 391. Recoge también la famosa expresión orteguiana sobre la cultura entendida como «movimiento natatorion. Un bracear del hombre en el mar sin fondo de su existencia con el fin de no hundirse... De ahí el valor de la cultura para salvar al hombre de ese hundimiento.

15 Op. cit., pág. 202. 
Constitucional. Recoger todas estas expectativas es la meta de una Constitución que aspire a ser normativa, utilizando la terminología de Loewenstein, es decir responder a las expectativas reales de la sociedad en que se aplica ${ }^{16}$.

Siguiendo en esta misma línea, podemos añadir al concepto cultura el calificativo de democrática, máxime si tenemos en cuenta que el sexenio que nos ocupa, es para muchos autores el "democrático" por excelencia de la historia española, con más propiedad que «revolucionario". Y la cultura democrática, como recuerda Manheinn, tiene sus propios mecanismo de comportamiento. De entre éstos destaca la capacidad para disminuir la "distancia vertical» entre gobernantes y gobernados. Intento de superar la "distanciación" que es algo connatural a toda sociedad organizada jerárquicamente. En una cultura democrática, como recuerda el sociólogo alemán, lo importante no es la persona, sino la obra. El personaje, por muy egregio que resulte - aquí entraría en juego toda la teoría de las «elites» de Pareto a Michel, de Mosca a Weber -, queda al final condicionado por la "obra" que lleva a cabo. Proyectando este esquema sobre la España del último tercio del siglo $X I X$, nos encontramos con una colección de grandes protagonistas históricos que va a hacer posible un proceso de modernización política cuya plasmación jurídica sería la Constitución de $1869^{17}$. Siguiendo a Sorokin, la personalidad de los protagonistas, como sujetos de la interacción social, la sociedad como totalidad de las citadas personalidades en interacción y la cultura como totalidad de las significaciones, valores y normas poseídos $y$ compartidos por las personas en su interacción, son los elementos básicos e indispensables para conocer en profundidad la realidad social en su conjunto, y además ninguno de los tres puede ser estudiado sin tener en cuenta a los otros miembros de esta trinidad ${ }^{18}$. Llega a afirmar que "Personalidad, sociedad y cultura son una trinidad inseparable".

16 El Derecho asi entendido es lo que explica la variedad de sistemas jurídicos existentes y la dificultad de encontrar un orden normativo único para las distintas sociedades, cada una con su correspondiente y personal cultura. De ahí también el fracaso de la pretensión de un teórico neutralismo científico.

17 Véase Karl MANHEINN en Ensayos de Sociología de la Cultura, Madrid, 1963. Especialmente págs. 290 y ss.

18 SOROKIN: Sociedad, cultura y personalidad, Madrid, 3. ${ }^{a}$ ed. 1966, págs. 98 y ss. 


\section{LA HISTORIA INTEGRAL}

Teniendo en cuenta todo lo anterior, pretendemos acercarnos a la Constitución de la Gloriosa desde una concepción integral de la Historia, que nos permita la más exacta comprensión de la misma, sus causas y sus efectos ${ }^{19}$. La Constitución se presenta así como el retrato oficial del país en un momento determinado. Esta foto será más o menos real en función de la autenticidad que el constituyente haya querido darle al texto. Cuando el fotógrafo constituyente quiera distorsionar la imagen a través de una constitución semántica, utilizando el término acuñado por Loewenstein ${ }^{20}$, el resultado será la deformación de la realidad reflejada en la norma. La opinión de actores ajenos al poder constituyente permitirá comprobar hasta qué punto la realidad cultural subyacente, entendida en sentido amplio, fue respetada por los autores de la Ley de Leyes.

Analizar y contrastar la realidad expresada en el texto, aconseja según Mitteis, tener en cuenta no sólo las fuentes estrictamente jurídicas, sino también las narrativas, los eventos artísticos de la época, la prensa, memorias y diarios de los principales "actores" en el sentido sociológico de la expresión. Esta nueva orientación metodológica fue recogida en nuestra patria por el profesor García Gallo quien lleva a cabo «una búsqueda realista del Derecho, concebido éste como la "ordenación de la vida social con fuerza vinculante" y englobado dentro del amplio marco de la cultura" ${ }^{21}$. Con ello nos situaríamos en

19 El concepto de Historia Integral fue introducido en la historiografia española por Rafael Altamira en su Historia de la Civilización Española, Barcelona, 1902, según señala el profesor Jover. Los contenidos de la misma serían «los hechos políticos, las instituciones sociales y políticas, las actividades económicas, la religión, las ciencias y las artes, las costumbres" (JOVER, op. cit., päg. 308). Más adelante el profesor Jover destaca la importancia que tuvo la traducción española de la obra de Arnold HAUSER The Social History of Art por la Ed. Guadarrama, Madrid, 1957, 3 vols., al «difundir entre nosotros la noción de la estrecha conexión existente entre arte, literatura y sociedad, contribuyendo así, en no escasa medida, a facilitar una concepción integral de la historia de la cultura" (nota $n .^{\circ} 39$ a pie de la página 330 de la obra citada).

20 En su obra Teoría de la Constitución, Barcelona, 2. ${ }^{\circledR}$ ed. 1976.

21 Los profesores MonTANOS FerRín y SÁnCHEZ ARCILLA, en su Introducción a la Historia del Derecho, Dykinson, Madrid, 1988, vol. I, págs. 26 y ss., han reivindicado para el maestro García Gallo el haber introducido en nuestra patria las nuevas corrientes realistas del derecho que fuera de nuestras fronteras practicaban Koschaker, Mitteis o Wieacker. Como señalan los citados profesores, "esta nueva corriente se centra en las situaciones básicas en torno a las que se articula la vida 
lo que se ha llamado la "historificación de las constituciones", que resalta la importancia de los análisis históricos al estudiar las normas constitucionales, que en un principio y para algunos autores sólo era necesaria en el caso británico, dada la importancia del factor histórico en su desarrollo constitucional, pero que hoy es admitida casi unánimemente por la doctrina como dato fundamental para el análisis de cualquier ordenamiento jurídico. Barthelemy y Duez reiteran machaconamente esta necesidad. Entre nosotros, el Profesor Clavero, en su Manual de Historia Constitucional de España sigue esta misma orientación metodológica, también visible en Tomás y Valiente cuando define la Historia del Derecho como «ciencia que debe estudiar el núcleo normativo $y$ técnico del Derecho y su objetivación en instituciones, pero sin perder de vista quiénes crean el derecho, quiénes pues tienen el poder para crearlo, cómo lo aceptan o lo resisten quienes no gozan de poder, cómo lo aplican y recrean los técnicos del derecho, los juristas etc.».

\section{UNA CUESTIÓN METODOLÓGICA. FUNCIONALISMO Y ESTRUCTURALISMO}

Llegados a este punto, se impone encontrar un método que permita mezclar adecuadamente los planteamientos históricos con los sociológicos, económicos y jurídicos. Parece que en la síntesis metodológica entre el estructuralismo y el funcionalismo podría estar la solución adecuada, en la línea señalada por Bobbio, aunque es claramente perceptible en el profesor italiano una mayor preferencia por las tesis funcionalistas. En este sentido es tajante cuando afirma: "Al haber aumentado enormemente las funciones del Estado (...) el pro-

social. Esto nos lleva necesariamente al encuentro de las instituciones o relaciones básicas y fundamentales de una sociedad. En las instituciones se pueden apreciar tres elementos: en primer lugar, las situaciones de hecho, que se pueden producir con o sin la voluntad del hombre; en segundo lugar, la valoración que el hombre hace de estas situaciones conforme a sus ideas e intereses religiosos, politicos o económicos; $y$, por último, lo propiamente jurídico de la institución, la regulación que hace el hombre de esas situaciones de hecho conformes a la valoración que ha hecho previamente de ellas. Lo jurídico es una parte de la institución, no la institución misma, y es en este aspecto en el que debe centrarse la investigación del historiador del Derecho, pero teniendo presente los restantes", op. cit., págs. 27-28. La cita es larga pero muy ilustrativa en cuanto a los planteamientos metodológicos. 
blema fundamental para una teoría sociológica del derecho, es decir para una teoría que considera el Derecho como un subsistema del sistema social general, es el problema de verificar si no han aumentado, $y$, paralelamente, cambiado, las funciones del Derecho - se entiende del Derecho Estatal - , lo que explica la imprevista emergencia y la rápida difusión de la perspectiva funcionalista» 22 . De esta cita se desprende una doble cuestión. Por un lado, han aumentado las tradicionales funciones estatales, y por otro se ha producido un cambio en las mismas que corre paralelo a la evolución del aparato estatal ${ }^{23}$.

Entre nosotros el Profesor Jorge de Esteban optó decididamente por el método funcional en sus análisis constitucionales ${ }^{24}$. Evidentemente, una interrelación metodológica estructuralista-funcionalista

22 Contribución a la Teoría del Derecho, Valencia, 1980. Edición a cargo de Alfonso Ruiz Miguel, pág. 265.

23 El tema metodológico es de una importancia extraordinaria sólo comparable a su también extraordinaria complejidad y dificultad.Para empezar carecemos de una definición precisa, aceptada por todos sobre el significado de ambos términos, es decir estructuralismo y funcionalismo. Hay quien sitúa en Kelsen el origen del estructuralismo jurídico, al concebir el Derecho como una totalidad, como una estructura completa. Para el profesor HERNÁNDEZ GIL, «El estructuralismo es fundamentalmente un método" (Estructuralismo y Derecho, Alianza Universidad, Madrid, 1973, pág. 23. Se trata de una obra colectiva resultado de un curso de doctorado impartido por el citado profesor en la Facultad de Derecho de la Complutense durante el curso académico 1971-72, y recoge los trabajos presentados en dicho curso por algunos alumnos. Para el tema que nos ocupa resulta interesante la afirmación del Profesor MESA MEngliar, quien pone de relieve la importancia del estructuralismo para el estudio, entre otras materias, de la Historia del Derecho, op. cit., pág. 152).

Bobbio se encargaría de canalizar la evolución del estructuralismo - de clara raíz diltheana, en opinión de FERRATER MORA (Diccionario de Filosofía, Buenos Aires, 1975, vol. I, pág. 588) - hacia el funcionalismo.

Al igual que carecemos de un concepto univoco de Estructura, tampoco existe en la Teoria del Derecho una elaboración rigurosa de lo que se entiende por Función. En el Congreso Internacional de Filosofía del Derecho, celebrado en Madrid en 1973 no se llegó a un acuerdo sobre el concepto. El Profesor Ferrari al describir las funciones del derecho las define como "objetivos primarios asignados al Derecho por los actores sociales o bien, en otros términos, como finalidad respecto a la que se ordena el uso de aquella modalidad de acción social que hemos definido como jurídica, que consiste en la persuasión de los interlocutores a través de la influencia de mensajes normativos hipotéticos, institucionales y justiciables" (Funciones del Derecho, Ed. Debate, Madrid, 1989, pág. 107). Por otro lado, no puede concebirse el funcionalismo como un método alternativo al estructuralismo, sino que ambos se interrelacionan mutuamente.

24 Constituciones Españolas y Extranjeras, 2 vols., Taurus Madrid, 1977. Especialmente vol. I, págs. 22 a 47. 
permite conocer tanto la Constitución como el régimen político al que sirve de norma fundamental. Hace posible llegar al fondo de las instituciones que contempla, analizar sus fundamentación histórica, el estado de las fuerzas sociales subyacentes, el papel de las elites, los procesos de socialización política, el concepto de ciudadanía y la toma de conciencia de los ciudadanos ante los problemas fundamentales del país. En términos unamunianos nos permite llegar a conocer la intrahistoria que tantas veces aparece aplastada y oscurecida por la historia superficial.

En este sentido, y a lo largo de este trabajo, pretendemos analizar la Constitución de 1869 de acuerdo con esta metodología, haciendo especial hincapié en la función legitimadora, la ideológica, la política y la transformadora, en un intento de ver hasta qué punto el texto reflejó la "cultura política" del país en ese momento dado, las esperanzas que levantó y las frustraciones que originó.

Pero desde los presupuestos de una "historia integral" que reflejara la cultura política dominante en un momento determinado, la norma constitucional no era sino la resultante de una relaciones de poder subyacentes que daban su ritmo y orientación a la nueva situación que creaban. De esta forma la Constitución trasladaba al esquema normativo las ideas políticas de los grupos instalados en el poder. Ello justifica que casi tan importante como el análisis del texto constitucional, resulte la descripción de los grupos de poder dominantes. Es decir, de lo que Artola llama el "bloque de poden más o menos integrado en el sistema de poder y con la pretensión de ocuparlo en su totalidad e influir al máximo en el mismo ${ }^{25}$. Lo que sucede es que en esta nueva cultura política que se está generando en los años cincuenta y sesenta del régimen isabelino, participan y confluyen una pluralidad de fuerzas políticas que, en principio, sólo coinciden en la necesidad de destro-

25 Los conceptos que utiliza ARTOLA son:

1. "Sistema político", es decir, "el conjunto de participantes que intervienen en la formulación de decisiones y las normas a que se ajustan en su acción».

$2 .^{\circ}$ "Sistema de poder", en el sentido que "las instituciones son, en última instancia, las fuerzas encargadas de imponer a la sociedad, la aceptación y realización de tales decisiones".

Distingue también entre "clases hegemónicas ", también llamadas "clases reinantes", que son las que establecen las pautas a seguir, y las llamadas "clases de apoyo", en las que las hegemónicas seleccionan el personal que integran los cuadros directivos de la Administración del Estado, para traducir en hechos y realidades concretas sus principios políticos y económicos.

Véase Partidos y Programas Politicos, pág. 179. 
nar a la Reina. Y el instrumento que lo haría posible era fundamentalmente una revolución. De ella coincidian todos en su necesidad. Discrepaban bastante en cuanto a sus consecuencias $y$ el alcance que podría darse a la misma. Por eso hubo coincidencia en Cádiz y discrepancia a partir de Alcolea. De ahí que tan importante como el análisis del texto resulte el estudio de lo que cada una de las partes entendía por revolución y el contenido objetivo de la misma. La elaboración del texto no será a la larga más que la expresión normativa de las ideas políticas del grupo dominante, que coincidía en casi todo con los restantes sectores políticos que habían ayudado mancomunadamente a la caída de la dinastía, pero que sin embargo discrepaban en un tema clave: la forma de gobierno. Esto explica que lo que en principio había de ser el hecho histórico determinante - la Constitución- acabe jugando un papel secundario, y refleje la ruptura de los ideales políticos que habían hecho posible la revolución de septiembre. Esto justifica también que a lo largo de las Constituyentes se oiga hablar mucho más de revolución - para muchos traicionada y frustrada - que de modelo constitucional propiamente dicho. De esta manera, la Revolución se transforma en el eje central de la vida política del sexenio. A su alrededor giran como satélites el resto de los grandes temas. De ahí la necesidad de conocer el trasfondo histórico, político, cultural y social del país en esta época. Y acabemos refiriéndonos a la idea madre del sexenio, sobre la que se asientan todas las demás, incluida la propia constitución. Esta idea es la Revolución y el concepto que cada uno tiene de ella. Es decir, proyectar sobre el texto constitucional el concepto de revolución, ver su alcance y la plasmación que en el articulado se refleja de la misma, mezclando el método funcionalista con el estructuralista.

Todas las fuerzas que habian colaborado a la revolución de septiembre eran conscientes de la necesidad de contar cuanto antes con una Constitución, aunque las razones de la necesidad fueran distintas. Los partidos gubernamentales necesitaban el texto para superar lo que había de interinidad y provisionalidad en su ejercicio del poder. Las fuerzas republicanas para tener un punto de referencia en sus críticas al Ejecutivo, máxime después de la manera que han tenido de resolver el tema de la forma de gobierno. Para todos, la Constitución venía a significar la plasmación jurídica de esa nueva etapa en la Historia de España, abierta en septiembre de 1868. Todos, en fin, habian puesto en la Constitución futura sus sueños de presente y de pasado. Los republicanos soñaban con que el final de Isabel II era también el fin del monarquismo en España. La mayoría gubernamental, por el contrario, entendía que el "Abajo los Borbones" significaba exclusiva- 
mente la expulsión de esa familia, pero dejaba abierta la puerta a otras dinastías, manteniendo la forma monárquica de gobierno. En el fondo, todas estas discrepancias encontraban justificación en la idea que cada uno tenía de la revolución que se había llevado a cabo. De ahí que el propio concepto de Constitución, aparecería íntimamente ligado al de Revolución, y a la idea que cada uno tenía de la misma. Juntos para derribar el trono de Isabel, se separan cada vez más cuando tienen que decidir la solución de recambio. A partir de aquí empiezan las acusaciones de unos sobre otros acerca el alcance de la revolución. Alguno se preguntará incluso si valía la pena haber arriesgado tanto para conseguir tan poco, al menos en el orden formal.

La elaboración de la Constitución va poniendo de manifiesto las profundas diferencias entre los actores políticos de la revolución septembrina. El texto resultante va a ser incapaz de actuar y servir de elemento de integración política, con todo lo que ello significa ${ }^{26}$. Como señala el profesor Lucas Verdú, es determinante el papel que puede juggar la clase política, tanto gobierno como oposición, "para intensificar el vínculo moral que une a los ciudadanos con sus instituciones". Desde este planteamiento, el texto de 1869, reflejará en su estructura interna el techo ideológico de las fuerzas políticos mayoritarias ${ }^{27}$. Estas fuerzas son tres. El partido progresista que aportará su tradición avanzada y las masas necesarias para ganar una elecciones. La Unión Liberal conectado con lo mejor del generalato y una incipientes clases medias. Por último, los demócratas serán la savia intelectual, los hombres de ideas y en última instancia los que logran dar el tono al texto constitucional y el estilo a los debates parlamentarios.

La Constitución de 1869 va de este modo a legitimar aquellas fuerzas políticas que hasta hace poco se encontraban a gusto en el régi-

26 La importancia del tema ha sido puesta de relieve entre nosotros por el Profesor don Pablo LuCAS Verdú en El sentimiento constitucional, Ed. Reus, Madrid, 1985.

27 Utilizo la expresión "estructura interna» en el sentido puesto de relieve por el Profesor FERRANDo BAdiA, en una obra que lleva precisamente este título (Estructura Interna de la Constitución, Tiranch lo Blanch, Valencia, 1988), o el Profesor JIMÉNEZ DE PARGA en su obra, ya clásica, Los regímenes políticos contemporáneos, Madrid, 1974. En opinión de ambos, el texto constitucional tiene que responder a las tres cuestiones fundamentales de la convivencia política: ¿quién manda?, ¿por qué manda? y ¿cómo manda? Una respuesta en profundidad exige superar el enfoque estrictamente constitucionalista y adoptar un método más próximo a la sociología política, para analizar las fuerzas sociales y políticos que constituyen el entramado de cada régimen político. 
men isabelino, pero que llegada la hora de la verdad y al ver cómo este había agotado todas sus posibilidades, no dudan en eliminar a una Reina y su Camarilla, de la que muchos habian formado parte y todos habían servido. Para esta operación de derribo cuentan con fuerzas abiertamente monarcómanas que más tarde se van a sentir defraudadas y que serán ignoradas cuando ya no sean necesarias para apuntalar el nuevo régimen.

La función legitimadora de la Constitución tiene también una proyección internacional. Europa necesita saber el quantum de revolución están dispuestos a aplicar los políticos septembrinos. Los europeos de a pie ven con simpatía el movimiento revolucionario español, mientras que sus gobernantes lo observan con recelo, conscientes del efecto contagioso que puede tener sobre otros pueblos. La Constitución vendrá a tranquilizar a estos políticos, que ven cómo la revolución ha sido encauzada una vez más en un texto de escasa vigencia. Constitución y Revolución se nos muestran así como el binomio indispensable para comprender la función legitimadora que viene a cumplir el texto de 1869.

El problema, sin embargo, estriba en el distinto significado que el término revolución tiene para unos y otros. La diferencia no es sólo en cuanto a sus resultados finales, sino incluso al mismo punto de partida, a su inicial planteamiento. El por qué y para qué se hace la revolución, tiene distintas lecturas en función del lado del espectro político que se tenga en cuenta.

\section{LA TEORÍA DE LA REVOLUCIÓN}

Nada más constituirse definitivamente las Cortes Constituyentes, surge en el seno de las mismas el debate sobre el sentido y alcance de la Revolución de Septiembre. El tema estaba en la calle desde el momento en que se produjo, pero desde septiembre del 68 a febrero del 69, las distintas fuerzas políticas han ido observándose mutuamente y cada cual procura tomar posiciones para cuando llegue el momento constituyente. De ahi que el primer debate sobre el contenido y alcance de la Revolución, tenga lugar cuando se pone en marcha el Parlamento recién elegido. Era hasta cierto punto lógico. Las Cortes eran el escenario más adecuado para amplificar las distintas tesis políticas. De ahí que el tema saliera a relucir, en fase constituyente, por boca de su Presidente don Nicolás María Rivero. Al dar las gracias por su elección para presidir estas Cortes, afirma que las reglas, 
credo y principios escritos en la bandera de la revolución de septiembre son "los principios democráticos en su más alta expresión. Si Señores; la revolución de septiembre es eminentemente democrática; en todas partes acepta y proclama como símbolo suyo a la democracia, que es la última forma del progreso humano en el estado actual de la civilización de los pueblos» ${ }^{28}$. Los principios que nutren esa "democracia" son en su opinión los siguientes: soberanía nacional, derechos individuales, y sufragio universal. Es fácilmente visible que los dos primeros son los postulados básicos de la Revolución Francesa y aparecen contenidos en todas las constituciones liberales de la época, formando el esqueleto del llamado "Estado de Derecho". La inclusión del término "sufragio universal", introduce una variable democrática que hasta esa fecha estaba prácticamente ausente de todos los países de Europa. Hay que reconocer que en este tema, España fue una auténtica pionera al establecer el sufragio universal masculino como una de las grandes conquistas de la revolución de septiembre.

En el análisis del Diario de Sesiones de las Constituyentes, sorprende que los principales protagonistas de la Revolución, apenas se plantean el tema revolucionario stricto sensu. Todos hablan de revolución, todos la dan por hecha y al final se dividen en dos grandes grupos: los que creen ser fieles al espíritu revolucionario - el gobierno y su mayoría parlamentaria-, y los que opinan que la Revolución ha sido traicionada - la minoría republicana - . Pero ninguno habla de las ideas fundamentales de la revolución. Sólo están de acuerdo en una cosa: el punto de partida. La expulsión de la Reina y la familia Borbón. Pero falta toda una construcción teórica sobre los grandes principios. Da la impresión de que la revolución se agota con la salida de la Reina y su camarilla. $Y$, a lo largo del debate constitucional, siempre que se habla de revolución se identifica con forma de gobierno. Falta la exposición de las «ideas madres» que acompañan a todo auténtico movimiento revolucionario. La exposición de las ideas fundamentales que justificarán el cambio grandioso que se auguraba. Quizá la explicación estribe en que no hacía falta explicar las razones del cambio, conocidas por todos - la teoría de los obstáculos tradicionales-, pero en cambio sí era necesario señalar la orientación de ese cambio y las consecuencias del mismo. Y lamentablemente tampoco se llevó a cabo. Y eso que tomaban asiento en las Cortes una generación de hombres cuya categoría intelectual sólo sería equiparada en las Constitu- 
yentes de 1931. Son los llamados "Demócratas de cátedra". Esos hombres que, como advierte un personaje de Galdós, hicieron de 1869 «un año de acciones difusas y de oratoria sinfónica» ${ }^{29}$, aludiendo con ello a la falta de concreción de sus propuestas, que sin embargo se presentaban envueltas en un lenguaje exquisito.

Pero el problema principal que se van a encontrar los miembros del Gobierno Provisional reside en la falta de sintonía con las masas que le han aupado al poder. Y ello se explica porque uel sentido de la revolución se encarnaba en las Juntas con mayor autenticidad que en el Gobierno" ${ }^{30}$. He aquí un dualismo de poder al que más tarde habré de referirme. Un sinnúmero de Juntas, en plural, en las que se han agrupado de forma más o menos espontánea numerosos contingentes de ciudadanos de a pie que viven la utopia de la revolución, como la milagrera solución de todos sus sempiternos problemas. Enfrente, un Gobierno que ha llevado la iniciativa, respaldado al principio por las Juntas a las que más tarde vaciarán de poder y contenido. Una vez más el problema político del juntismo español y las frustraciones consiguientes.

El mismo dia de la constitución definitiva de las Cortes Constituyentes - el 22 de febrero de 1869- tiene lugar un debate en el que participan algunos de los mejores oradores de todos los tiempos. Empieza Rivero afirmando sin empacho que «España acaba de consumar la más grande y la más maravillosa de las revoluciones, reflejando en ella el carácter que durante la larga historia de este glorioso pueblo le ha distinguido de todos los demás del mundo»" ${ }^{31}$. El político sevillano da por sentado el " hecho revolucionario" que en su opinión debe verse traducido en la constitución que las Cortes deben elaborar, cerrando asi «el largo período constituyente que nuestros padres abrieron con tanta gloria en las Cortes de Cádiz». Una vez más, y como ha puesto reiteradamente de relieve el profesor Jover, estamos ante la invención de una tradición constitucional que luego intentaremos desvirtuar con el mismo entusiasmo que pusimos en su búsqueda.

El Marqués de Albayda toma la palabra entrando directamente en el tema de la forma de gobierno e identificando revolución con república. Recuerda que el 30 de noviembre de 1854, con 22 diputados más,

29 Episodios..., vol. III, pág. 899.

30 Véase Fernández Almagro, op. cit., pág. 23.

31 DSCC n. ${ }^{\circ} 10$, pág. 84. 
solicitó un cambio en la forma de gobierno, que fue rechazado por las Cortes Constituyentes. La consecuencia de aquella negativa fue, en su opinión, la acentuación del carácter reaccionario en la monarquía isabelina. La revolución que ha expulsado a la Reina no puede restaurar una monarquía, aunque sea sin borbones y se apellide democrática. Pregunta abiertamente a la mayoría: «si de las teorias doctrinarias habéis pasado a la democracia, ¿por qué no habíais de pasar a la República?» ${ }^{32}$.

En la misma sesión parlamentaria Castelar, después de llevar a cabo una serie de acusaciones contra el Gobierno Provisional, proclama que "el error de los errores, el más grave error, fue después de haber preparado, como he dicho, la opinión de las potencias extranjeras, levantarse un día el Gobierno, y en vez de atenerse a lo que la voluntad nacional dijera, proclamar la forma monárquica como la forma de la revolución. Por este error, señores, por este solo error, yo no votaría al Gobierno provisional una acción de gracias»" ${ }^{33}$. Lamenta el haber hecho una revolución para entregar el poder al ejército y que éste haga de la restauración monárquica la pieza central de su gobierno. En este sentido hay por parte del orador gaditano una abierta acusación al gobierno de pretorianismo. Conviene recordar que en ocasiones anteriores ha habido gobiernos presididos por militares. Tal es el caso de Narváez y O'Donnell. Pero "no gobernaron en militar (...) los dos se asistieron de hombres civiles» que en muchas ocasiones dieron su "tono" a los gobiernos de que formaban parte ${ }^{34}$. Termina afirmando que "como Escipión sabéis vencer, pero no sabéis aprovecharos de la victoria". El catedrático de Historia se impone una vez más al orador. El intelectual al político ocasional. Pone de relieve la contradicción que supone levantarse contra la monarquía y proclamar la forma monárquica como la forma de gobierno de la revolución. Teme la influencia del ejército como institución en el proceso constituyente y niega que la revolución sea la obra de un militar por muy ilustre que pueda ser. Topete, Prim y Serrano han contribuido a ella y la han abanderado, pero la revolución es algo más y necesita más ayudas del cuer-

32 DSCC n. ${ }^{\circ} 10$, pág. 94.

33 DSCC n. ${ }^{\circ} 10$, pág. 103.

En su ataque al Gobierno, Castelar procura no entrar en el terreno personal, al contrario de lo que sucede con ORENSE, quien llega a decir en las Cortes que "los ministros primerizos (se refiere a Topete) son medianos. La segunda vez que entran, malos. La tercera hay que echar a corrern, pág. 94 del Diario de Sesiones.

34 Ésta es la tesis de Fernández Almagro, op. cit, vol. II, pág. 9. 
po social ${ }^{35}$. No puede ignorarse que, desde el primer momento, junto al protagonismo militar están destacados civiles, sin los cuales tanto en la emigración como en el interior, la acción revolucionaria hubiera sido imposible. Cuando Prim llega a Cádiz a bordo de un remolcador el día 17 de septiembre, viene acompañado por hombres tan ajenos a la milicia como Ruiz Zorrilla, Sagasta y Paul Angulo, además del Coronel Merelo. El almirante Topete le llevaría a la fragata "Zaragoza" que mandaba el capitán Malcampo.

Cristino Martos, contestando a Castelar, se remonta a los orígenes de la revolución, que "vino por una serie de conspiraciones y desastres, vino por la alianza del partido democrático con el partido progresista, y la prenda de la alianza de esos partidos no fue una forma de gobierno; fue primero una negación, y luego la afirmación de los derechos individuales: lo primero que se pactó fue el destronamiento de la dinastía, y si alguna frialdad pudo haber en cierta ocasión entre los dos partidos, fue cuando sin razón pudieron recelar algunos que el partido progresista no estaba resuelto a destruir la dinastía de los Borbones». Martos, desde su posición de cimbrio (demócrata que, frente a su primera opción republicana, está dispuesto a aceptar la monarquía), justifica la alianza entre progresistas y cimbrios, pero demuestra una vez más que el núcleo fundamental de la revolución será el tema de la forma de gobierno ${ }^{36}$. Ciertamente hay más temas y

35 Contesta asi indirectamente a una afirmación anterior de Prim ante las Constituyentes, en la que el Conde de Reus afirmaba que Serrano y él mismo prepararon la mina revolucionaria y Topete le aplicó la mecha. Fue el mismo día -22 de febrero de 1869 - en el que pronuncia sus tres famosos "jamás" sobre la vuelta de los Borbones, y cuando por tres veces califica de "imposible» restaurar la dinastía caída. (DSCC, págs. 88-89). TOPETE, por su parte, en esta misma sesión, habla de la fragata "Zaragoza" como el "Arca de la Alianza" donde tiene lugar el pacto final entre Serrano y Prim. Reclama mantener la unidad que entonces se consiguió porque "la revolución se hizo embarcados; para salvarla es preciso la unión. Cuando uno se embarca no queda más que una disyuntiva: o llegar a puerto o naufragar: pensadlo y meditar». Se observa claramente en el tono de los discursos la clara conciencia de los militares sobre su paternidad en la revolución.

36 DSCC n. ${ }^{\circ}$ 10, pág. 107.

La contestación de Martos es un modelo de elegancia parlamentaria, por otra parte muy frecuente en estas Cortes. Empieza haciendo un gran elogio de Castelar y su elocuencia (reconoce que le pasa como a un diputado francés que tenia que replicar a Polignac y dijo: "Tengo que hablar y aún estoy oyendo a mi adversarion), para a continuación atacar a fondo. Entre otras cosas, destaca el hecho de que Prim, Serrano y Topete supieron hacer lo que los políticos «de siempre» no pudieron o no supieron: encontrar el momento adecuado para canalizar todas las fuerzas subyacentes en la revolución. 
muy importantes. Piénsese en la libertad de cultos, los derechos individuales y el sufragio universal. Pero la diferencia estriba en que todos ellos son asumidos por casi toda la cámara y desde luego por la minoría republicana. En lo único que discrepan y de lo que sacarán una valoración distinta de la revolución es en el tema de la forma de gobierno. Por si quedara alguna duda sobre la importancia del tema de la forma de gobierno, añade: "Cuando la Unión Liberal vino a esta alianza y aceptó el pacto que ya existía entre los dos partidos, democrático y progresista, la Unión Liberal quiso hacer lo mismo: concurrir a la grande obra que con tan escasa fortuna habiamos intentado nosotros: destruir la dinastía de los Borbones y fundar la libertad en España por el planteamiento del sufragio universal. Ya se sabía que la Revolución, que no era obra de la idea republicana, aunque era obra y resultado de la idea democrática, no había de dar por producto la república, no debía ser republicana, no debía tener una resultancia republicana, y no la tuvo. El Gobierno provisional sabía perfectamente que la revolución se habia hecho con las fuerzas combinadas de los tres partidos políticos, ninguno de los cuales quiso imponer forma determinada de gobierno, aunque todos convinieron en la esencia $y$ en el procedimiento de la revolución ${ }^{37}$.

Al día siguiente, y sobre el mismo tema - la proposición de acción de gracias al gobierno provisional-, toma la palabra Figueras, para insistir en la acusación al gobierno de haber incumplido los deseos revolucionarios acerca de la República. Llega a afirmar que «los derechos fundamentales del hombre sólo pueden garantizarse bajo la forma republicana»38. Se aprovecha cualquier situación para, venga o no a cuento, insistir en la identificación revolución-república. Se trascendía el tema de la forma de gobierno y se situaba esta cuestión en la esencia misma de la revolución. Ser republicano era la única forma posible de ser revolucionario y fiel al espíritu de septiembre. Algo muy parecido sucederá en 1931, aunque en este caso y de la mano de Azaña el binomio "revolución-república» se identifica con España. Son varios los discursos del político alcalaino en que esta equiparación es patente, lo que suponía calificar de antiespañoles a los que no comulgaran con las ideas republicanas ${ }^{39}$.

37 Ídem, pág. 107.

38 DSCC, pág. 116.

39 Se ha hecho poco hincapié en las raíces septembrinas de la obra política de Azaña. Sirva de muestra el hecho de que para muchos españoles su urevelación" como político tiene lugar en el discurso que pronuncia en 1930 en el banquete aniversario de la I República Española. 
La palabra revolución será el nombre mágico que todos utilizan para justificar su posición. Se habla mucho más de Revolución que de Constitución en unas Cortes... Constituyentes. La Revolución lo inunda todo y los conceptos políticos que están en el ambiente giran, todos ellos, alrededor de este tema tabú y sagrado para los hombres de 1869. Todos también, salvo los tradicionalistas, hacen encendidos elogios de la misma. Sorprende que personas de talante tan moderado como Topete lleguen a decir en el hemiciclo que uel 17 de septiembre es la fecha de la revolución más trascendental y radical que registran los fastos de nuestra historia" ${ }^{40}$. En términos muy similares se pronuncia Cristino Martos («la más grande y legítima revolución de la Historia»)47, y así podrían multiplicarse los ejemplos.

Figueras, en su intervención, lamenta el cambio de orientación que está recibiendo la revolución e insiste en el tema de la república como uno de los grandes objetivos de septiembre, hasta el punto de que, cuando tiene que atacar a los miembros del gobierno provisional, el calificativo más hiriente que encuentra es el de "monárquicos impersonales" a la búsqueda de un rey para España ${ }^{42}$, y lamenta la "abdicación vergonzosa" que supone la delegación de poderes que la Asamblea ha hecho en favor del General Serrano, poniendo de relieve, con gran habilidad, las diferencias entre el Presidente del Gobierno Provisional y su ministro de la Guerra ${ }^{43}$.

Sigue hablándose de la Revolución y de lo que cada uno entiende por tal. Moret afirma que la española de 1868 fue una amalgama de conservadores y demócratas. Los primeros pusieron la fuerza. Los

En cuanto a la identificación República-España en la obra azañista, dato que esta ausente en las Constituyentes del 69, la explicación, en mi opinión, es que en el 69, aunque ya han aparecido sintomas de catalanismo politico, sin embargo no ha adquirido la carta de naturaleza que tendrá en 1931. Recuérdese que en el Pacto de San Sebastián la presencia catalana es sobre la base de un futuro reconocimiento de la autonomía. Todo ello condicionaria la estructura del llamado "Estado integral» que aparece configurado en el texto del 31 y dirigido fundamentalmente a resolver el llamado "problema catalán".

40 DSCC, pág. 88.

41 Ídem, pág. 104.

42 A la vista de estos esfuerzos, Javier Pérez Rovo ha llegado a calificar a Amadeo de Saboya como "rey de importación".

43 En un excurso histórico compara la relación Serrano-Prim en 1869 con la de Espartero-O'Donnell en 1854, cada uno representante de tendencias dispares y de distintos temperamentos personales y políticos. Teme que lo mismo que pasó entonces, pueda suceder ahora, $y$ las diferencias entre ambos den al traste con la revolución. 
segundos las ideas y, en nombre de todos, el ejército salvó el espíritu de la Revolución ${ }^{44}$, entendiendo por tal el "obrar de acuerdo con la justicia y el derecho". Cuando el general Serrano se presenta ante las Cortes, afirma que el Gobierno que preside no ha presentado ningún programa, "porque su programa es el de la revolución de septiembre» 45 . En cambio, para Sánchez Ruano «la levadura de la reacción ha corrompido la masa de la revolución" y el proyecto de Constitución es el programa idóneo no de una revolución sino de la contrarrevolución. Una profunda desilusión es perceptible en los diputados republicanos al poco tiempo de abrirse las Constituyentes. Los ejemplos podrían multiplicarse. Todos se apoyan y justifican en la Revolución, pero pocos dicen lo que entienden por ella. De entrada parece posible deducir una diferencia fundamental. La revolución, para el Gobierno, es fundamentalmente política. Para la oposición es más amplia. Debe aspirar a cambiar no sólo la política sino también la sociedad. Debe ser más extensa y al mismo tiempo más profunda. Más de fondo y menos de forma. Llegar a la raíz en lugar de limitarse a consolidar el sistema de poder que ya está presente en la superficie. Naturalmente las diferencias eran tan profundas, que difícilmente podrían conciliarse.

Da la impresión de que todas estas sesiones fueran de tanteo, para cuando la Comisión de Constitución plantee los grandes temas. Son incidencias que permiten ir deslindando los futuros campos de batalla parlamentaria. A veces es también perceptible en la intervención de algunos diputados el hecho de considerar su presencia en las Cortes como representantes de la Revolución más que de la nación, que es a la que en realidad y en el juego constitucional representan, en virtud del mandato representativo del que se encuentran investidos. Fernando Garrido llega a decir que "estamos aquí en virtud del derecho de insurrección» 46 .

Quizá el alcance exacto de la Revolución fuera el que siente Segismundo, personaje galdosiano de "La España Trágica» cuando dice: «çon la mano puesta sobre el corazón del Pueblo, yo he meditado en el problema político; yo veo muy claro que la Gloriosa de Septiembre fue tan sólo el acopio de materiales para la Revolución que piden a voces el alma y el cuerpo de nuestra razan ${ }^{47}$. Frente a las denuncias $y$ aseveraciones de los políticos en activo, el deseo revolu-

44 DSCC, pág. 171.

45 DSCC, pág. 207.

46 DSCC, pág. 428. En el debate planteado por Garrido con motivo de la defensa de su proposición para la supresión de las quintas.

47 Galdós, op. cit., Episodios..., vol. III, pág. 975. 
cionario, utópico como fin, pero realista como diagnóstico de un ciudadano de a pie. Este personaje intuía que Cádiz era sólo un anuncio incompleto de lo que podía haber sido. Un aviso que se quedó sólo en eso, en una llamarada de ilusión inevitablemente condenada al fracaso. Sin ser un sociólogo, el Segismundo galdosiano estaba comprobando que, como ha escrito Manheinn, en toda revolución hay una especie de anticipación de futuro como consecuencia de la mezcla de elementos racionales e irracionales que acompañan el evento revolucionario. Él, como tantos españoles, tomó conciencia de que "le han robado" su Constitución, pero deja abierta la posibilidad de que alguien en el futuro retome la antorcha. Unamuno, muchos años más tarde, se preguntaba: ¿A cuántos renovó su vida aquel "destruir en medio del estruendo de lo existente"?, como decía Prim, porque para millones de hombres fue el mismo sol después que antes del 29 de septiembre de 1868 , las mismas sus labores, los mismos los cantares con que siguieron el curso de la aradan. La respuesta a la interrogante de Segismundo se intenta llevar a cabo en un primer momento con los movimientos anarquistas, condenados al fracaso al pretender imponer una concepción quiliástica de la existencia en un mundo plenamente moderno. Y por parte de la burguesía ilustrada española en los albores de los años treinta. No es ninguna casualidad que los republicanos del 31 , es decir los nietos del 68 , proclamen con orgullo sus raíces septembrinas y sueñen con ser los realizadores de las ideas de la revolución y superadores del fracaso de la misma.

Los razones de este fracaso quizá estriben en la pluralidad de causas que conducían a la revolución - sobre la existencia de múltiples causas hay una rara unanimidad entre todos los estudiosos del tema- y el hecho de que algunas de ellas eran francamente incompatibles entre sí. Jutglar escribe sobre el particular: «En resumen, frente a los intentos más moderados de los grupos más acomodados, los movimientos pequeño burgués y proletario se desarrollaron en dos líneas que no llegaron a converger durante el período de la revolución septembrina. En esta no convergencia, debe buscarse la clave del fracaso revolucionario: el movimiento iniciado en septiembre de 1868 fue la suprema ocasión que tuvieron los núcleos burgueses hispanos para alcanzar plenamente unos objetivos, pero no fueron capaces de evitar el desbordamiento de los cauces de la vida española, en un movimiento tan imperioso que todas las instituciones fracasaron en su intento de controlar la situación» ${ }^{48}$.

48 "Fenomenología Social de la Revolución», Revista de Occidente n. ${ }^{\circ}$ 67, Madrid, 1968, pág. 137. 
La revolución como fenómeno dual, no sólo en el terreno social sino incluso geográfico - teoría del doble eje Madrid-Barcelona-, así como económico e ideológico - moderantismo versus radicalismoexplica, en opinión de Jutglar, el sexenio democrático y su fracaso en la historia española del siglo XIX y hasta el XX, pues su influencia superó con mucho los límites estrictamente cronológicos ${ }^{49}$. Las diferencias entre el centro y la periferia, la teoría de los dos ejes - político y económico - representados por intereses contrapuestos, ayudan a comprender la gran frustración del 68. Vicens Vives explica estas contradicciones con base en la ruptura del llamado «pacto triangular» entre Cataluña, con las necesidades y condicionamientos de la industria textil, el País Vasco, con su incipiente siderurgia en un ámbito social muy anclado en el pasado, y los intereses cerealistas de castellanos y andaluces. Cincuenta años más tarde y en vísperas de otra "revolución" se volverá a hablar de la oligarquía andaluza de la vid y del olivo, la cerealista de las dos Castillas y la industria catalana y vasca.

En la revolución española de 1868 hay una voluntad política de cambio por parte de sus dirigentes, pero de un cambio controlado, "procesual» utilizando la terminología de Rosenstocks o Arendts. Crear un nuevo orden en el sentido germinal que toda revolución lleva implícita y que esta nueva organización de la convivencia siguiera controlada por los mismos sectores sociales que habian servido al régimen anterior. De ahi que se vieran abocados a cambiar urgentemente de posiciones políticas. Tiene lugar la «instrumentalización" de la Revolución. El cambio que la revolución postula será la función ideológica que ésta conlleva. Su traducción a un nuevo esquema normativo justifica la función jurídica. Las esperanzas que suscita llenan de contenido la función transformadora. El establecimiento de la monarquía democrática la función política. De esta forma, analizando la "anatomía" de la revolución en la terminología de Brinton, nos encontramos que el evento revolucionario en sí mismo concentra una serie de funciones, muchas de las cuales se quedarían en puro juego de artificio al faltar la base necesaria para su consolidación. Si desde el punto de vista funcionalista, la revolución tiene fácil acomodo, desde el planteamiento estructuralista faltaban las base sociales necesa-

Sobre la multiplicidad de causas en el origen de la revolución coiciden JOVER, lópez Cordón, Jutglar, Sánchez Albornoz, etc.

49 El tema desarrollado en extenso en el tomo XXXIV de la Historia de España de MENÉNDEZ PIDAL, págs. 647 y sS. 
rias. La sociedad española de 1868 tenía una plataforma muy precaria, un punto de partida muy deficiente en al ámbito social, político y económico. Como dice Vicens Vives había «varias articulaciones sociales». Se podría añadir que con escaso margen de colaboración. Unas veces se ignoraban mutuamente $y$ en contadas ocasiones se enzarzaron entre sí. La Restauración Canovista vendrá a consolidar esta situación y desde este punto de vista es el último capítulo de la revolución iniciada en Cádiz.

\section{MEMORIA HISTÓRICA Y SITUACIÓN POLÍTICA}

Es perfectamente perceptible tras la lectura del Diario de Sesiones que gran parte del problema de las Constituyentes es una cuestión de «memoria histórica». Ver dónde están en 1869, tras los sucesos revolucionarios, los que en años inmediatamente anteriores luchaban y aplastaban literalmente la revolución. Una de las grandes paradojas históricas es ver al frente de la revolución a quien había acabado con el levantamiento del cuartel de San Gil, recibiendo como premio por tamaña empresa el collar del Toisón de Oro. Todos se conocían lo suficiente para que una alusión personal pudiera justificar un serio debate parlamentario. Los cambios de situación política se dieron con más facilidad dentro del centro derecha que en otras formaciones políticas. La Unión Liberal tiene que esperar a la muerte de O'Donnell para aliarse con los progresistas. Dicha alianza, inconcebible bajo la jefatura del Duque de Tetuán (con los progresistas ni al cielo, habia sentenciado el duque), era asumible por el pragmatismo político de otro Duque, el De la Torre ${ }^{50}$. Las relaciones entre las distintas fuerzas políticas que

50 Ello no es óbice para que todos reconozcan la gran influencia de Serrano Domínguez en el seno del ejército. Castelar llega a afirmar en las Constituyen. tes, el 22 de febrero de 1869, que sólo esta reconocida influencia es lo que puede explicar el protagonismo político y la Presidencia del Gobierno Provisional en un hombre que sólo cuenta con 70 votos en las Cortes. (DSCC $n .^{\circ} 10$, pág. 99). Curiosamente, la sabiduría popular ha sabido calificar el oportunismo político del general, motejándole con el apelativo de "el judas de Arjonilla», en alusión geográfica a este municipio jienense en el que el Duque tenía una gran propiedad.

En un debate parlamentario que tiene lugar el día 3 de marzo de 1869 el general Pierrad recrimina a Serrano su derechismo. Éste, sin inmutarse, le recuerda a su antiguo camarada que usi las aguas del Jordán habían pasado por el Sr. Pierrad para que hoy pueda ser republicano, también pueden pasar por mi para que hoy pueda ser monárquico-democrático" (DSCC n. ${ }^{\circ} 17$, pág. 280). Ambos generales habían servido a la Reina y atacado al pueblo de Madrid. Ambos en 1856 eran 
integraron la mayoría gubernamental no eran precisamente un prodigio de amistad y camaradería. Estévanez recoge en sus Memorias los calificativos con que los unionistas designaban a su socio político, líder indiscutible y compañero de armas, el General Prim 51 .

Otro caso que llama la atención es el del Sr. Sagasta, antaño compañero de conspiración y exilio y uno de los diputados más agresivos y peleones de las Cortes, que hoy se encuentra muy a gusto en la mayoría gubernamental y que ostenta la cartera de Gobernación. El diputado Balaguer llega a calificarle de "liberticida" ${ }^{52}$. Naturalmente todo cambio de posiciones, implica también una alteración en el plano del poder desde el punto de vista subjetivo. Se está a favor de lo que antes se ha combatido, o se ataca lo que antes se ha aplaudido. Pero siempre habrá algún antiguo compañero de fila que no tenga reparos en recordarlo. Es la mudanza de los tiempos. Como casi siempre en determinados personajes de la "situación", la única tacha que puede hacerse a estos cambios es el que siempre se hagan en dirección al poder. En estos tiempos fue una práctica muy frecuente, lo que se explica en parte por el alto nivel de ideologización que vivía la

enemigos declarados de Sagasta, y en 1868 Serrano y Sagasta eran amigos y ambos enemigos de Pierrad. Los cambios de posicionamiento político estaban al orden del día.

51 «Aún después de concertarse con los progresistas, la inquina con que honraban los unionistas a Prim no podía ser más feroz: lo nombraban a menudo y siempre lo hacían para insultarle, llamándolo patuleo, pillo, ambicioso, cancano resucitado, noi con espuelas, pesetero y asesino" (Memorias de un Hombre de acción, pág. 149).

52 "Los que cuando hay libertad apelan a las armas, se suicidan. Los que esto hacen no son liberales sino liberticidas". DSCC, pág. 279.

Para su biógrafo y admirador el Conde de Romanones, Sagasta es la personificación del político, y con este calificativo titula su biografía. El político riojano fue siempre de un pragmatismo que en cada momento le dictaba el rumbo que había de tener su orientación política.

En la sesión del día 5 de marzo de 1869, una de las más borrascosas, Sagasta estuvo muy agresivo con todos los diputados republicanos. Además, es de los pocos que no respetan siquiera a sus grandes figuras como Castelar o Figueras. Esto es perfectamente visible en el Diario de Sesiones.

Sagasta fue el primer miembro del Gobierno que tomó la palabra en las Cortes, y a poco de inaugurarse éstas, el día 17 de febrero de 1869, tiene una fuerte agarrada con Orense por motivo de las elecciones. Albayda dice que son una "farsa indigna" y acusa de ello al Gobierno. Afirma también que "aquí no se triunfa nunca contra el Gobierno". DSCC n. 6 , págs. 54 y ss. Hace una fuerte crítica del caciquismo imperante $y$ se refiere a los cuneros, protegidos del gobernador "bajá de tres colas de las provincias de Españan (pág. 55). 
sociedad española en los años sesenta del siglo pasado. La Restauración vino a aguar esta situación y, en gran parte, su aceptación se debió al giro conservador y pacífico que supo darle a la misma burguesia que habia alentado la revolución septembrina. El antiguo conspirador se transforma en un ordenado y pacífico ciudadano, más atento a las fluctuaciones de la bolsa que a sus pasadas inquietudes revolucionarias. Es el tránsito de la "burguesía revolucionaria" a la "burguesía conservadora" ${ }^{53}$. Orense, con la franqueza política que le caracteriza, habla con frecuencia, al referirse a los demócratas, de la facilidad de que hicieron gala para cambiar de "amistades políticas". Joaristi recuerda a Sagasta lo que publicaba su periódico La Iberia contra las mismas personas que hoy son sus compañeros de gobierno ${ }^{54}$. El diputado García López llegaría a decir que los ministros militares son más respetuosos con la minoría republicana que los civiles, lamentando la animadversión de que hacen gala especialmente Sagasta, Figuerola y Ruiz Rodilla55. En el campo de la mayoría, el Dr. Mata, antaño republicano, es particularmente duro con sus antiguos compañeros de partido.

Las disfunciones que inevitablemente se tenían que producir entre los prohombres que habian dedicado gran parte de su vida a conspirar, pero que llegada la hora de la verdad se van a encontrar en campos distintos y en muchas ocasiones opuestos, explica los sucesos de Cádiz y Málaga ("borrones de la revolución», les llama Figueras) y la reacción exagerada del gobierno en ambas localidades. Orense "honrado patriarca de la intransigencia" como le define Galdós ${ }^{56}$ llega a decir en las Cortes: «pasma ver cómo los hombres sostienen una cosa cuando no están en el poder y cómo luego practican otra muy distinta en los bancos ministeriales", lo que en su opinión va a dar lugar a que la revolución no se lleve a cabo y todo quede en un simple pronunciamiento57. Más adelante se referirá a los "políticos veletas, de los que hay tantos en España y que le dan ascon, en

53 Éste es el título que dan a su obra ARTOLA y MARTinez CUADRADO, respectivamente, en los volúmenes V y VI de la Historia de España de Alfaguara, Madrid, 1973.

54 DSCC, pág. 192.

55 DSCC, pág. 479.

56 Op. cit, vol. III, pág. 1153.

57 DSCC, pág. 321. Orense en la oposición y Sagasta en la mayoría, antiguos compañeros de conspiración, dan la impresión de ser diputados muy agresivos y peleones, que además no se arredran ante nada ni ante nadie, por muy consagrado que pueda estar. 
una clarísima alusión a Sagasta. El marqués de Albayda reprocha al ministro de la Gobernación la falta de limpieza de las elecciones y lo compara con "los grandes electores de las épocas anteriores" 58 Una vez más, se estaba planteando la diferencia, a la hora de analizar los problemas de la convivencia, entre la respuesta de los hombres de acción que se adaptan inmediatamente a la situación por muy cambiante que ésta se presente y el intelectual que necesita distancia histórica para reflexionar y emitir su pensamiento. Cuando carece de distancia, en lugar de "reflexionar", se limita simplemente a "opinar". Weber ha escrito páginas ya clásicas sobre este dualismo intelectualpolítico ${ }^{59}$.

En el distinto punto de mira que los antaño amigos de conspiración tienen sobre el concepto y alcance de revolución, hay ocasiones en que se pierde la compostura parlamentaria - muy pocas veces - y se hacen acusaciones de gran calado político. En este sentido un sector de la mayoría suele acusar a la minoría de ser más socialista que republicana, preferir la igualdad a la libertad y defender la primacía del Estado con la consiguiente anulación del individuo. Es el caso de Figuerola para rebatir a Pi y Margall60. Ello explica las declaraciones de Figueras ${ }^{61}$ a favor de la propiedad privada, o las de $\mathrm{Pi}$ en pro de la libertad. En el mismo sentido, la fuerte acusación de Castelar a la mayoría gubernamental llamándoles "esclavos de un amo" a lo que contesta Moret calificando a los republicanos de «cortesanos de las masas" ${ }^{62}$. Martos, contestando a Figueras por alusiones, reconoce que uel día 17 de septiembre de 1868 se ha abierto un abismo entre el presente y el pasado. De un lado del abismo estamos todos los que queremos el progreso de la revolución de septiembre, la conservación de las libertades públicas y el engrandecimiento del país; del lado opuesto están los que han querido hundirse con la dinastía. Yo no tengo que mirar, yo no miro ese abismon ${ }^{63}$. El Doctor Mata acusa

58 Llega a decir que «donde las elecciones son limpias, sobran las revoluciones y los pronunciamientos». En su réplica, Sagasta elogia la limpieza electoral y afirma que han participado más de 3.300 .000 electores, que sin apenas perturbaciones han hecho uso del sufragio universal. DSCC, págs. 356 y ss.

59 Max WEBER, El politico y el científico, Madrid, 1969.

60 DSCC n. ${ }^{\circ} 12$, pág. 155.

61 La lectura atenta del Diario de Sesiones revela la gran autoridad moral de este tribuno, perceptible en la forma de dirigirse a él los demás diputados, tanto de la mayoría como de la oposición.

62. DSCC n. ${ }^{\circ} 44$, de 8 de abril de 1869 , págs. 930 y ss.

63 DSCC $n .{ }^{\circ} 11$, de 23 de febrero de 1869, págs. 127-8. 
a los republicanos, antiguos compañeros de filas, de "ser los representantes de la utopía". Godínez de Paz los acusa de "haber elevado a la categoría de principio político la simple cuestión de la forma de gobierno". Desde los bancos republicanos, un hombre tan cuidadoso de las formas como Castelar no duda en llamar a los diputados de la mayoría "revolucionarios de agua dulce" destacando la falta de armonía entre la Constitución que se ofrece y la revolución por la que se luchó64.

La memoria histórica se recuperará ya en pleno siglo $X X$, cuando tras la reflexión social y política que se abre con la crisis del 98 , de nuevo los españoles miren hacia su pasado para acabar con su presente. $Y$ de esa vuelta al pasado, el punto de referencia va a ser la obra política y jurídica del sexenio. Desde el punto de vista político la nueva "apelación a la república»; desde el punto de vista jurídico la recuperación del corpus jurídico presente en la Constitución de 1869. Si ésta había sustituido a la Constitución isabelina por excelencia -la moderada del 45-, la Constitución del 31 instalaba en la Historia del Derecho Español a la doctrinaria del 76. Desde el punto de vista ideológico, se recogían los principios del humanitarismo y la democracia y se trasladaban al Estado Social de Derecho de la Constitución de la II República, concepto que se introduce por primera vez en nuestra patria. Desde el punto de vista social, será también la burguesía la que pretenda controlar la situación. Si Castelar apela a una república con mucha guardia civil, Alcalá Zamora pensará en obispos y arzobispos de la curia española. Hay que destacar sin embargo que esta nueva burguesía, a diferencia de la anterior, no es especulativa, sino ilustrada, abierta a la participación del proletariado con la inclusión en el gobierno del partido socialista y radicalmente opuesta al liderazgo militar en los asuntos políticos españoles. Todos ellos van a procurar evitar los radicalismos. Saben que por ese camino la revolución nueva que predican se les puede ir de la mano como se fue la de sus abuelos. Antonio Machado, en un mitin electoral en Segovia el año 1931, dice que "la revolución no es volverse loco y alzar barricadas; es algo tal vez menos violento pero más grave». El poeta advierte a los asistentes que una cosa es la revolución y otra el estruendo. Azaña, en circunstancias parecidas apelará una vez más a la memoria del español medio y le recriminara su capacidad de olvido. Parece como si el político alcalaíno, nieto de miliciano liberal, estuviera anticipando la famo- 
sa tesis de Milan Kundera: "La lucha del hombre contra el poder es la lucha del hombre contra el olvido".

\section{CONCIENCIA DE «CRISIS» Y ALCANCE DE LA MISMA}

La revolución habia venido a poner sobre el tapete de la realidad histórica española una larga crisis que se venía gestando desde hacía algunos años. Crisis importante en cantidad y calidad, puesto que no hubo un solo espacio en el que no se hiciera sentir. Era una crisis de múltiples registros. En principio la revolución respondía a la crisis del pais, y la ponia de manifiesto. En este contexto, la Constitución sería una especie de vademecum que contuviera la receta idónea para resolver el problema -es decir, la crisis o las distintas crisis-, y al mismo tiempo justificar y legitimar la revolución.

\section{a) Crisis política}

Hay en primer lugar una crisis política, entendida como crisis del sistema y cuya existencia nadie discute. A lo sumo se puede discrepar sobre su inicio. Hay bastante unanimidad en señalar el Manifiesto del Partido Progresista del 8 de septiembre de 1863, como el punto de partida $^{65}$. El Manifiesto, redactado por Olózaga, preconizaba el «retraimienton del partido para no concurrir a las elecciones convocadas para el día 11 de octubre de 1863, como consecuencia de la disolución del parlamento el 12 de agosto del mismo año. Va firmado por las grandes figuras del partido progresista, Prim, Sagasta, Ruiz Zorrilla, Madoz y Figuerola, y supone la ruptura de las reglas de juego que hasta entonces habían mantenido la vigencia del régimen isabelino. No era la primera vez que el progresismo había amenazado con la abstención, a la vista de la conducta de la Reina, pero la gravedad de este caso es que tal acuerdo está tomado por unanimidad. Ello suponía dejar al descubierto el esqueleto del sistema. A partir de aquí se viviría el vértigo de

65 Con anterioridad, el día 30 de agosto de 1863, tiene lugar el llamado "Manifiesto de los Mínimos". Un sector muy reducido del partido progresista que permanecía en Madrid cuando los demás miembros del partido se habían marchado de vacaciones, elabora un documento instando al partido a que no participe en las elecciones. Es el principio del retraimiento. 
la cuesta abajo de una forma imparable ${ }^{66}$ En el "retraimiento" está, pues, la partida de nacimiento del hecho revolucionario. Como señala Andrés Borrego, la retirada electoral de los progresistas "estaba destinada a ser el punto de partida, el eje principal, la llave maestra del movimiento, cuyo término condujo al destronamiento de la Reina y a la caída de la dinastían ${ }^{67}$.

El día 3 de mayo del año siguiente tiene lugar el llamado "Banquete de los Campos Elíseos" convocado por el partido progresista y al que asisten más de 3.000 comensales. El General Prim, conspirador, revolucionario y guerrillero a un tiempo, pero ante todo y sobre todo político de raza ${ }^{68}$, anuncia a sus militantes que "antes de dos años y un día" habrán desaparecido los obstáculos tradicionales, a los que se refería Olózaga, quien también tomó la palabra en este acto.

La publicación por parte de Castelar del artículo "El Rasgo" y la negativa del rector de la Central, Juan Manuel Montalbán, a expulsar al catedrático gaditano, como pedia Narváez, justifica el abandono de un amplio sector de la inteligencia española respecto del Régimen. Junto a Montalbán presentan su dimisión Morayta y Salmerón ${ }^{69}$. EI nuevo Rector, el marqués de Zafra, se ve impotente para cortar la sangría de abandonos en solidaridad con Castelar. A raíz de esta expulsión tiene lugar la llamada "Noche de San Daniel", que precipitaría la salida del gobierno del general Narváez. El 10 de abril de 1865 quedará en el recuerdo de los universitarios españoles como uno de los días

66 Para el profesor EIRAS ROEL, de este gesto salió la revolución. Idéntica es la opinión de la profesora LÓPEZ CORDón.

67 Libro de las Elecciones, Madrid, 1874, pág. 36. Cit. por CARRo, op. cit., pág. 20.

68 Llama la atención el entusiamo que despertaba el general en amplios sectores sociales. GaLdós, en La España Trágica, le llama «El León» y cuando comenta su asesinato en la calle del Turco dice que «a la epopeya española del XIX le faltó el lado trágico: matar a un Rey. En su lugar mata a Prim». Paul y Angulo, en su periódico El Combate, solia referirse a Prim con el sobrenombre de "El Mito". Se le acusó de estar involucrado en el magnicidio del día 27 de diciembre de 1870, que costó la vida al general. Pero nada se ha podido probar a pesar del exhaustivo análisis de los más de 18.000 folios del sumario, que llevó a cabo Antonio PEDROL Rius.

69 Los estudiantes de la Central habían convocado una serenata a su ex rector el Profesor Montalbán, que vivia en la calle Santa Clara. La Guardia Civil impide la celebración del acto y los ánimos siguen caldeándose. El lunes día 10 de abril, al mismo tiempo que el marqués de Zafra va a posesionarse del rectorado, hay una manifestación ante Gobernación. González Bravo lanza a los guardias contra los estudiantes. 
más negros de su historia ${ }^{70}$. La contestación por parte del gobierno y la explicación de los mismos correrá a cargo de González Bravo, quien en un ejemplo de resistencia y elocuencia, o elocuencia resistente, pronunciará 18 discursos en ambas cámaras. Fiel a su vocación conspiradora, el 9 de junio se presenta Prim en Valencia para iniciar un nuevo pronunciamiento que también fracasaría. Era Teniente Coronel de la plaza D. Manuel Pavía. El 21 de junio O'Donnell sustituye a Narváez. El 28 de septiembre el comité dirigente del partido progresista se reúne en el Circo Price de Madrid. Cada dia el partido es más antidinástico y por lo tanto anti-régimen, dada la identificación que ha llevado a cabo entre Corona-Estado y Dinastía-Régimen Político. Las fuerzas politicas que sostienen a la Reina se van reduciendo. Ya sólo cuenta con los moderados y los unionistas. Los progresistas se presentaban como "víctimas políticas" del exclusivismo gubernamental de moderados y unionistas, como ha destacado la profesora López Cordón ${ }^{71}$. El general Prim se incorpora abiertamente al progresismo. La incompatibilidad entre los "obstáculos tradicionales» y los principios progresistas es cada día mayor. El 5 de octubre de 1865 tiene lugar la concentración de los demócratas en la madrileña Plaza del Rey. Ese mismo día los moderados celebran conciliábulo en casa del Duque de Veragua. Todas las fuerzas políticas viven una especie de hervor pre-revolucionario. Se publica en El Diario Español el artículo «Meditemos», firma-

70 Ruiz Zorrilla se apresura a derogar la legislación de 1866 y restablecer con carácter provisional la de 1857. El periódico La lberia del día 1 de octubre de 1868 publica el siguiente suelto: “Rogamos a la Junta Revolucionaria de Madrid que fije su atención en todos y cada uno de los catedráticos, en su mayor parte de REAL ORDEN, que vergonzosamente accedieron a la imposición del gobierno borbónico firmando exposiciones de servil adhesión a la digna hija del monarca narizotas.

Al mismo tiempo, y ya que tenemos las manos en la masa, recordaremos que en la Facultad de Medicina no hay más que UN SOLO catedrático propietario por ÓPOSICIÓN (sic). Los demás... real orden».

El Imparcial del dia 3 de octubre comenta: «Han sido repuestos en sus cátedras de la Universidad Central por la Junta Revolucionaria los señores Salmerón, Castelar, Sanz del Río, Castro y otros, únicamente separados por un poder conculcador de todas las leyes y todos los derechos".

El día 4 de octubre la Junta Revolucionaria de Madrid acepta la renuncia de Sanz del Río al rectorado de la Universidad y se lo encomienda a don Fernando de Castro.

Según recoge la prensa de la época, el día 24 de octubre llega a Madrid Emilio Castelar. Es recibido por la banda de música del Hospicio, que le espera en la estación del Norte, donde le rinden honores un batallón de Voluntarios de la Libertad.

71 Op. cit., pág. 454. 
do por Álvarez de Lorenzana, y el día 3 de enero del nuevo año tiene lugar el pronunciamiento de Villarejo de Salvanés, con Prim como cabeza visible ${ }^{72}$. El punto de inflexión será sin embargo el levantamiento del cuartel de artillería de San Gil, el día 22 de junio de 1866. Los sargentos se insurreccionan y, dirigidos por Pierrad e Hidalgo, se enfrentan a las tropas de Serrano, el futuro dirigente de la revolución. Son fusiladas 66 personas, casi todas ellas sargentos del arma de artillería. Cae el Gobierno O'Donnell el 10 de julio, no sin antes advertir que la sangre del pueblo está ya peligrosamente cerca de la alcoba real. Sube al poder Narváez de nuevo. Su antecesor volvería a España una vez muerto en el exilio voluntario de Biarritz el 4 de noviembre de $1867^{73}$. Las fuerzas anti-isabelinas siguen organizándose. El 16 de agosto de 1866, se reúnen en Ostende Sagasta, Ruiz Zorrilla, Becerra, García Ruiz y los generales Prim, Pierrad y Milans del Bosch, entre otros. Es la consagración oficial de la unión entre demócratas y progresistas.Se constituye un comité para coordinar los esfuerzos de la conspiración, integrado por Prim y Aguirre, por los progresistas, y Becerra por los demócratas. Todos aceptan el sufragio universal como el instrumento idóneo para resolver los distintos problemas de gobierno que puedan surgir. Sobre el resto de los temas se deja su solución para un futuro, una vez que triunfe la revolución. Este se haría notar especialmente en la cuestión de la forma de gobierno y en el debate parlamentario subsiguiente. El dia 4 de noviembre el general Carlos María de la Torre reconoce como Jefe de la Revolución al General Prim, en el llamado Manifiesto de Bruselas. El año 1866 termina, desde el punto de vista económico, casi como empezó. Una grave crisis social y un profundo crash económico. El 7 de enero de 1867 se da a conocer el llamado Manifiesto de Madrid, donde por primera vez se hace públi-

72 Cuenta con los regimientos "Calatrava" y "Bailén». Tras el fracaso escapa a Portugal, para desde allí marchar a Londres. A pesar de sus repetidos fracasos, Prim era hombre de gran moral, al que no arredran ni los fracasos conspiratorios ni las decepciones e incluso traiciones de sus compañeros de armas.

Tras la fracasada intentona del 3 de enero, Castelar, Rivero y Martos, según Méndez Bejarano, se refugian en casa de Justo Horacio Perry, agregado de la legación norteamericana en España y que tenía magnificas relaciones con los conspiradores, aprovechándose en cierto modo de su inmunidad diplomática. OLtRA incluye este dato en nota a pie de página $n .^{\circ} \mathbf{4 0}$ de su citada obra.

73 Según GaLDós, de una indigestión de ostras. En el episodio nacional titulado "La de los Tristes destinos", dice del Duque de Tetuán que «no hace, pero deja deshacer" (vol. III, pág. 725). Recoge también el comentario de O'Donnell cuando es llamado a palacio para cesarle: «Me han despedido como despedirían ustedes al último de sus criados". Añade que "era como un niño grande». 
ca la coalición antidinástica. El 28 de marzo se abre una legislatura con amplio dominio de los moderados, que se cierra el 13 de julio del mismo año. El 30 de junio de 1867 tiene lugar la reunión de Bruselas, a la que asisten todas las cabezas visibles de la revolución salvo Pi y Castelar. El 27 de diciembre de este año se abre la última legislatura del reinado de Isabel II, que sería cerrada por un Real Decreto de 19 de mayo de 1868, que suspende sus sesiones. El 20 de abril muere Narváez y el 23 accede al gobierno González Bravo, el antiguo revolucionario Ibrahim Clarete, seudónimo con el que firmaba sus celebres artículos satíricos en el periódico El Guirigay, periodismo de gran violencia que contribuyó decisivamente a la caída de la Reina Regente ${ }^{74}$. Su gobierno se va a caracterizar por lo que Fernández Almagro denomina "una ciega resistencia a la desesperada» 75 . El 8 de agosto de 1868, Isabel II abandona el palacio de La Granja y se traslada a Lequeitio. Nunca más regresaría a la Corte, como reina en ejercicio. De allí a San Sebastián el día 17 de agosto, después de aceptar la dimisión de González Bravo y designar al Marqués de La Habana, D. José de la Concha, como Presidente del Gobierno el día 20 de septiembre. El día 19 tiene lugar el levantamiento de la Armada en Cádiz al grito de "Viva España con honra " ${ }^{76}$ y surgen los "Voluntarios de la libertad». Comienza lo que Joaquín Costa llama "la pirotecnia de Cádiz». A destacar el dato de ser sólo los militares los que firman el Manifiesto. Hay una "deliberada exclusión de hombres civiles". El 28 de septiembre tiene lugar la batalla de Alcolea ${ }^{77}$. Hay una profunda desmoralización entre

74 Su pragmatismo era tan grande que años más tarde propuso el retorno de la Reina Cristina desde París, donde se encontraba, olvidando los soeces vocablos que le había dirigido desde El Guirigay. Pasó a la más extremada reacción. Fue el inventor de las famosas "cuerdas de Leganés", así llamadas por el modo de trasladar los prisioneros. Hombre muy violento, dirigió la sangrienta represión de la Noche de San Daniel en su condición de Ministro de la Gobernación del Gabinete Narváez. Al ser discutida su actuación en el Consejo de Ministros, dio tales pruebas de virulencia verbal que provocó la muerte de su compañero de Gobierno don Antonio Alcalá Galiano, el famoso orador de Cádiz y el protagonista de La Fontana de Oro de Galdós. Murió el 11 de abril de 1865.

75 Op. cit., pág. 14.

76 Natalio Rivas dice que el Ministro de Marina, don Martín Belda, futuro marqués de Cabra, respondía de la lealtad de la escuadra en 1868. También le sorprende que un conspirador nato como era González Bravo no se hubiera dado cuenta del alcance de la revolución. Op. cit., pág. 145.

77 Serrano es consciente de la escasa rentabilidad política de una confrontación armada. Por ello envià a Benjamín Fernández Vallín a parlamentar, pero es fusilado por las tropas de Novaliches. Repite el intento, esta vez con éxito, en 
las fuerzas monárquicas. Desde diversos sectores se busca una salida a la crisis política y dinástica a un tiempo pidiendo a la Reina la abdicación a favor del Príncipe de Asturias y encargando la Regencia, durante la minoría de edad, al General Espartero. La idea no cuajó, lo que hace imparable la revolución ${ }^{78}$. La Reina, acompañada de Marfori sale para $\mathrm{Pau}^{79}$ como primera parada de su exilio, que se establecería en el bautizado Palacio de Castilla en la avenida Kleber de la capital de Francia. La revolución está dando sus primeros pasos. En el viejo edificio de la Aduana aparece un cartel con la leyenda "Cayó para siempre la raza espúrea" y muy cerca otro que decía "Pena de muerte al ladrón". Es el trasunto de los famosos carteles revolucionarios del París de 1848. El dia 3 de octubre de 1868 llega Serrano a Madrid, tras una breve parada en Pinto para saludar al General Pavía y Lacy, Marqués de Novaliches, el derrotado en Alcolea ${ }^{80}$. El día 7 Prim hace acto de presencia en Madrid. El 9 se constituye el Gobierno Provisional y el día 11 tras el mitin de Albayda se produce la escisión de Rivero y Martos, quienes el 12 de noviembre harán público el llamado Manifiesto de los Cimbrios. Todos estos hechos tan sucintamente expuestos van a ser fundamentales en el desarrollo de la revolución y el alcan-

la persona de Adelardo López de Ayala. Se llega a una especie de pacto tácito que permita a los soldados isabelinos salir con honra del campo de batalla. Igualmente a sus jefes. Es conocida la sentida visita de Serrano a Novaliches en la localidad de Pinto a interesarse por sus heridas y llorar juntos los males de la patria. Como se sabe, el general Novaliches fue herido por un casco de granada en la mandíbula.

78 Cuesta trabajo pensar que los progresistas, con Prim a la cabeza, hubieran aceptado esa solución, que dejaba sin efecto todos sus planes revolucionarios, a pesar del "guiño" político que supone acordarse de Espartero. Es en cierto modo el mismo "detalle" que Prim tendría con el Duque de la Victoria, ofreciéndole el trono de España, en carta entregada en mano por Madoz, en la certeza de que no aceptaria, lo que le dejaba las manos libres para buscar "su" candidato.

79 Se instala precisamente en el castillo que fue el solar originario de la casa de Borbón.

80 Junto a Novaliches mandó tropas en Alcolea el Conde de Girgenti, "único Borbón que en aquellas circunstancias, criticas para su familia, supo o quiso cumplir con su deber. Al frente de un regimiento de caballería concurrió a la batalla de Alcolea; perdida la batalla, y no ciertamente por su culpa, se quedó solo, desamparado, sin saber dónde se habían metido sus cortesanos de la víspera $y$ sus aduladores de todos los momentos. Si no tuvo que irse enteramente solo desde el campo de Alcolea hasta la frontera lusitana, lo debió al republicano don Estanislao Figueras, que lo acompañó con riesgo de la vida». EstÉVANEz, op. cit., pág. 165. 
ce de la misma. Para muchos la Revolución, que había empezado con el "retraimiento" progresista de 1863, terminaría cuando el Gobierno Provisional tome los poderes que le transfiere la Junta de Madrid y asuma todas sus competencias. Han sido 6 intensos años de conspiración e ilusión. Lo que viene después es el desánimo y el desencanto de quienes luchan contra Isabel y muy pronto van a ver a otro Borbón, a su hijo, sentado de nuevo en el trono de España ${ }^{81}$. El momento prerrevolucionario ha durado exactamente lo mismo que la Revolución: un sexenio. La ilusión de la víspera no se vio correspondida por la realidad de la llegada82. La revolución "estaba destinada a perecer a manos de sus autores", como escribió Estévanez ${ }^{83}$. Un personaje galdosiano afirmaba que "la revolución que traen se quedará en un juego de militares" 84 .

81 Se iba a dar el caso curioso de reinstalar en el trono caído de los Borbones al más Borbón de todos los reyes de España. Alfonso XII es Borbón por partida cuádruple. Oficialmente al menos es Alfonso de Borbón y Borbón, Borbón $y$ Borbón. La reina Isabel es Borbón y Borbón, igual que el Rey Consorte (véase La otra vida de Alfonso XII, Ricardo DE LA CIERVA, Madridejos, 1994).

82 ESTÉVANEZ supo reflejar esta decepción en forma de versos satíricos en un poema titulado " 3 de enero", parodiando una rima de Bécquer $y$ alusivo a la forma de terminar la revolución: el golpe de Estado de Pavia. Dicen así:

"Volverá la partida de la porra

por mayor y menor a funcionar, volverán a romperle las costillas a todo el que trascienda a federal. Volverá la Duquesa de la Torre a vivir en la calle de Alcalá.

Pero los de las gorras coloradas, ésos no volverán.

Volverán calamares sin vergüenza

a transferir millones, a robar.

$Y$ volverán a España los Borbones,

$y$ frailes $y$ jesuitas volverán.

Y Maisonnave tornará a las bufas, y volverá a sus trinos Castelar.

Pero aquella gorrita colorada

no me la pongo más.» pág. 12.

Recogido por José Luis FernándeZ RúA en la Introducción a sus Memorias,

${ }^{83}$ Se trataba de un personaje muy singular. Con la República llegó a ser ministro, pero el cargo no lo aguantó más de un mes. Según Natalio Rivas, murió arruinado y sin embargo se negó a cobrar su pensión de ex ministro. Su probidad y honradez eran fuera de lo común. (Anecdotario Histórico, pág. 95).

84 Op. cit, vol. III, pág. 759. 


\section{b) Crisis dinástica}

Pero la crisis política no es la única, aunque seguramente sea la más importante. Coexistiendo con ella, hay otras manifestaciones de la quiebra en que vive la sociedad española de la época.Crisis que se solapan unas a otras, pero que todas conducen al mismo fin: mostrar al país las entrañas de un sistema que estaba podrido de raíz. Dada la identificación entre la Corona y el régimen político en que se asentaba para la opinión pública no era nada desdeñable la crisis personal, familiar y dinástica de la Reina Isabel II. Es decir, el sentimiento de crisis estaba instalado en la mismísima cúspide del sistema. Una reina niña a la que la caída de Espartero, que abandona España el día 2 de agosto de 1843 , ha precipitado su mayoría de edad ${ }^{85}$. Se inicia un reinado de los más largos de la historia española, que dura de 1843 a 1868. Veinticinco años que dan su impronta a la llamada era isabelina. Jover ha señalado "los factores de continuidad" entre el largo reinado de Isabel y la revolución que la destrona. Leyendo la prensa y los documentos de la época da la impresión de que para los revolucionarios del 68 , la única causa de la revolución era precisamente la reina Isabel. Por ello tampoco puede extrañar que uno de los grandes objetivos a cumplir por los hombres de la Gloriosa, fuera precisamente para unos el cambio de forma de gobierno, y para otros el cambio de dinastía. Falta una brillante construcción teórica de las bases de la revolución, lo que es tanto más sorprendente dada la gran cantidad de buenas cabezas que en ese momento tomaban parte en la vida politica y cultural de España. La revolución va a ser para muchos la justificación de un cambio político reducido a un cambio... en el titular de

85 La caída de Espartero y su subsiguiente exilio es la culminación de una serie de conspiraciones, muchas de las cuales tienen su epicentro en París, en el círculo de la Reina Madre y su Serenísimo esposo el Duque de Riansares. La Regencia de Espartero se inicia el día 8 de mayo de 1841 y concluye el 2 de agosto de 1843, por la acción conjunta de Serrano, autoproclamado Ministro Universal en Barcelona, Narváez, que derrota al general esparterista Seoane en un simulacro de batalla en Torrejón de Ardoz, y Olózaga con su famoso discurso de los "salves". El llamado "General del Pueblo", cuyo lema era "hágase la voluntad nacional", estaba en un evidente deterioro político. Tomás Villarroya recoge una semblanza debida a Joaquín María LóPEZ que resulta definitiva: “... Apenas creado ese poder empezó a desmoronarse, pasando el pueblo que había proclamado el ídolo, de la idolatría al entusiasmo, del entusiasmo a la adhesión, de la adhesión al respeto, del respeto a la indiferencia, de la indiferencia al odio y del odio a lanzarlo a tierras extrañas donde pudiera entregarse al olvido de sus funestos errores o al melancólico recuerdo de sus glorias pasadas". 
la corona. A ello ha influido mucho el hecho de la identificación de Isabel con el régimen político que preside. La Reina como personificación del Régimen, ofrecía un campo de operaciones y el mejor blanco posible, sobre todo a partir de los hechos del cuartel de San Gil. Se identifica a Isabel II con los errores sangrientos de esta absurda represión.Después de 1865, como ha puesto de relieve Victoria López Cordón, "la monarquía isabelina sólo cuenta con la camarilla y algunos viejos políticos, leales a ella más por costumbre que por convencimiento" ${ }^{86}$. A partir de entonces será el punto de referencia de todas la conjuras revolucionarias ${ }^{87}$. Un perfecto chivo expiatorio al que abandonan todos, aunque cada uno por sus personales razones. También su propia familia. Hay una evidente crisis familiar y dinástica alrededor del trono.Toda su vida habia sido un centro de intrigas que alcanzan límites insospechados con motivo de su boda. Todos pretenden imponer su candidato para mejor asegurarse su participación en el poder. El conde de Trapani, Montemolín, y finalmente su primo don Francisco de Asís de Borbón. Un matrimonio desgraciado que quizá justificaba ante sí misma la agitada vida sentimental de la Reina que estaba en boca de todos ${ }^{88}$. La boda fue una operación de estado que tiene lugar el día 10 de octubre de 1846 con el doble enlace de la Reina con Francisco de Asís y su hermana, la Infanta Luisa Fernanda, con el duque de Montpensier, hijo del rey francés Luis Felipe. Las cancillerías extranjeras han jugado un papel decisivo en estos enlaces.Espa-

86 En Historia..., op. cit., pág. 441.

87 Isabel había nacido en el Palacio Real de Madrid a la cuatro y cuarto de la tarde del día 10 de octubre de 1830 y murió en el Palacio de Castilla de París a las ocho y cuarenta y cinco minutos de la mañana del dia 9 de abril de 1904. Mujer de escasa formación académica - Natalio RIVAs reproduce literalmente una colección de cartas y billetes escritos por la Reina con abundantes faltas de ortografía, siendo las más frecuentes la confusión entre la $\mathrm{B}$ y la $\mathrm{V}-$, toda su niñez y juventud estuvo presidida por las intrigas de unos y otros. Ella misma se lo confesaria en Paris a Galdós. "Ponte en mi caso. Carecí de gente desinteresada que me guiara y aconsejara. Los que podían hacerlo no sabían una palabra del arte de gobierno, eran cortesanos, que sólo conocían la etiqueta. Los que eran ilustrados y diestros en constituciones no me aleccionaban, dejándome a obscuras si se trataba de algo en que mi buen conocimiento pudiera favorecer al contrario. A veces me parecía estar metida en un laberinto por el cual tenía que estar palpando las paredes, pues no había luz que me guiara. Si alguien encendía la candela, venía otro y me la apagaba". No eran éstas las mejores credenciales para ponerse al frente de una España convulsa que vivió bajo su reinado dos guerras civiles y acababa de perder un imperio.

88 Sobre este particular se han publicado varias obras. La última de ellas es la de Manuel BarRios, Los amantes de Isabel II, Madrid, 1994. 
ña es el campo de actuación de grupos políticos y económicos que, al amparo de las leyes liberalizadoras, invierten en segmentos de gran valor estratégico y al final, cuando sus operaciones financieras no den el resultado apetecible, se plantearán la conveniencia de mantener el sistema sacrificando a la Reina. Estaba fuera de toda duda que el hijo del Duque de Cádiz, Francisco de Asís de Borbón y Borbón, era, como ha escrito Melchor Fernández Almagro, el personaje más «contraindicado para proporcionar a su cónyuge, la felicidad que física y moralmente pudiera apetecer" 89 .

Lo curioso del caso es que estamos ante una Reina irresponsable políticamente, por definición constitucional, y sin embargo se la hace responsable de todas las desgracias del país. Algunos de sus ministros "responsables" que han avalado con su refrendo los actos de la Corona, tardaron poco en pasar del servicio a los Borbones a ser ministros del gobierno provisional que sustituye a Isabel II. Figueras se lo recordaría muy elegantemente a Martos en el debate parlamentario ${ }^{90}$. Curiosamente casi todos los líderes de la revolución eran generales isabelinos, muy bien tratados por la Reina, alguno de los cuales gozó incluso de sus favores ${ }^{91}$. Pero sin embargo fue durante su reinado cuando tiene lugar en España «el desmantelamiento del Antiguo Régimen" si bien la "profundización del mismo tuviera lugar durante el sexenio", como ha demostrado Jover al hablar de la línea continua que une el reinado de Isabel con el gobierno de los que la destronan ${ }^{92}$.

La crisis familiar tiene una clara componente política. Ya de niña vio combatido su trono por su tío el Infante don Carlos $^{93}$. Más tarde su propia hermana se sumaria a los conspiradores septembrinos y su primo hermano, el infante D. Enrique de Borbón ${ }^{94}$, primer Duque de

89 Op. cit., pág. 8.

90 Véase DSCC, pág. 196.

91 Quizá se refiera a ello Ricardo DE LA CIERVA cuando, aludiendo a los devaneos amorosos de Isabel II, dice que se diferenciaban de los de otros reyes de España en que tenían consecuencias políticas. Este historiador señala también que la corrupción no sólo estaba en las gradas del trono. Los generales tampoco se escapaban del agio y poco podían echarle en cara a la Reina. De hecho, el militar español que más alto protagonismo ha jugado en la historia española -el General Serrano, tres veces Jefe de Estado y con tratamiento de Majestad- encontró en doña Isabel un magnífico trampolín para su ambición.

92 Introducción, Tomo XXXIV, op. cit., pág. XXV.

93 GALDós recuerda que los liberales le pusieron como mote "el alfeñique", op. cit., pág. 1427.

94 En el apéndice $2 .^{\circ}$ al Diario de Sesiones $n .^{\circ} 86$, se incluye con el $n .^{\circ} 347$ una petición que hace a las Cortes, desde París, don Enrique de Borbón, pidiendo 
Sevilla, perecería en duelo, víctima de una maquinación republicana que impidiera el acceso al trono de Montpensier, el candidato de Topete y la Marina ${ }^{95}$. El duelo, como decía un personaje de Galdós, «resultaba como una democratización de la realeza" y no pasaba de ser en opinión del mismo "una tragedia doméstica» ${ }^{96}$. Según Natalio Rivas, la única razón por la que Topete y la escuadra se sumaron a la revolución fue para destronar a Isabel y coronar a su hermana la Infanta Luisa Fernanda como Reina de España. Hacía tiempo que los Duques conspiraban contra Palacio. González Bravo se vio obligado a desterrarlos de España el 7 de julio de 1868. El gobierno puso a disposición de los duques la fragata "Villa de Madrid», que los trasladó de Sevilla a Lisboa, donde llegaron el 3 de agosto de 186897. Los afanes conspiratorios de los duques conocidos por todos, fueron revelados años más tarde por la Infanta Eulalia de Borbón, hija de Isabel II y nuera de

se le restituyan todos los honores que le corresponden. La Comisión de peticiones opina que no ha lugar a deliberar.

95 En un libro reciente de Manuel María Rodríguez de Maribona, titulado EI Ducado de Sevilla, se afirma que el Infante don Enrique de Borbón y Borbón fue asesinado, y no muerto en duelo por Montpensier como se ha creído hasta ahora.

Una autopsia solicitada por la familia tras la Guerra Civil del 36 demostro, según este autor, que el cadáver presentaba un orificio de bala por la nuca.

Natalio Rivas ha prestado especial atención a este extraño duelo, afirmando rotundamente que don Enrique no se bate con Montpensier por defender a su cuñada la Reina Isabel, sino que todo queda reducido a una maniobra republicana para eliminar a un candidato - Montpensier - al que respaldaba la marina $y$ los unionistas, es decir, Serrano y Topete, frente al General Prim y los progresistas. Tanto si moría en el duelo como si Montpensier mataba al Infante, quedaría eliminada su candidatura. El Infante manda un escrito al duque llamándole, entre otras cosas, "hinchado pastelero francés". Éste se considera ofendido y comisiona a los generales Fernández de Córdoba y Alaminos y al coronel Felipe Solís para que exijan al Infante que se retracte. Éste, a su vez, acepta el duelo y designa como testigos a don Federico Rubio y a don Emigdio Santamaria, ambos diputados republicanos. Quiso también contar con Espartero, pero el general se excusó, argumentando que estaba en. Logroño y con achaques de la edad. El duque de Montpensier, como ofendido, eligió arma: pistola. Fueron adquiridas en la Casa Hormaechea, de Madrid, calle de Alcalá n. ${ }^{\circ} 5$. El encuentro tuvo lugar el 12 de marzo de 1870 en Las Ventas de Alcorcón, a las 10 de la mañana, asistiendo como médicos los doctores don Luis Leiva y don José Sunsí. Por sorteo le tocó disparar primero al Infante, que no hizo blanco. Luego al Duque, que también falló. Al tercer disparo el francés mató al Infante. Véase RIVAS, op. cit., pág. 106.

El Duque de Sevilla había estado casado con doña Elena de Castellví, muerta prematuramente, de la que tenía una hija llamada María del Olvido de Borbón. 96 En España trágica, vol. III, pág. 928. Según GaLdós, fue el sábado 12 de marzo de 1870, entre Pozuelo de Alarcón y la carretera de Húmera. El nieto de Felipe Igualdad mata al nieto de Fernando VII.

97 Op. cit, pág. 98. 
Montpensier ${ }^{98}$. Como recordaba en carta a su esposa el escritor y diplomático Juan Valera, "la revolución va contra la dinastía" y entre sus principales arietes estaban personas muy próximas a la mismísima Isabel II99. La trascendencia de esta crisis dinástica y familiar no es sólo su importancia como elemento desencadenante y justificador de la revolución sino las consecuencias posteriores ${ }^{100}$. Puesto que en la contradicción de expulsar a un rey para restaurar la monarquía que incurrían a primera vista los constituyentes españoles del 69 , la clase política se veía abocada a la búsqueda urgente de un rey. Los debates constitucionales sobre la forma de gobierno corren paralelos a las preguntas e interpelaciones que hacen los republicanos sobre los distintos candidatos, cuyas biografías se van publicando en la prensa española ${ }^{101}$. Conviene resaltar que la prensa de esta época goza de una

98 Estaba casada con Antonio de Orleans y Borbón, primo hermano suyo, Duque de Galliera. El matrimonio resultó un auténtico desastre. La Infanta, posiblemente el miembro de la familia Borbón con más acusada personalidad, dice en sus Memorias: "Eran muchas las intrigas que cercaban el trono de España, pero el eje principal, por lo menos el hombre más temido en palacio, era el duque de Montpensier. Hombre culto, personalmente atrayente, simpático, enormemente rico, gran señor sin alardes y ducho en ambicionar sin límites, se había casado con Luisa Fernanda con la idea de llegar a ser Rey Consorte... La aventura de derrocar a mi madre costó al Duque la cantidad, entonces fabulosa, de 16 millones de francos, según me confiaba años después, siendo ya mi suegro...n, op. cit., págs. 10-11.

Además de este libro de memorias, la Infanta Eulalia escribió otro titulado Al filo de la vida, que causó gran revuelo y escándalo en las cortes europeas y en los círculos aristocráticos de la época.

Con el título Eulalia de Borbón, una madrileña universal, Madrid, 1992, se ha publicado una breve biografía por doña María Águeda CASTELLANo HUERTA.

99 Cartas..., Revista de Occidente, pág. 4.

100 Contra la tesis generalmente admitida de los errores de Isabel y su escandalosa vida entre las causas desencadenantes de la revolución, véase LORCA SIERO, que los niega rotundamente: "No se debe culpar a Isabel II del estallido de la Revolución de Septiembre, no ya sólo porque sería incurrir en una conclusión errónea y superficial, sino porque su vida privada no puede tener incidencia en la gobernabilidad del país y por sí sola no tendria la suficiente entidad como para provocar un cambio tan trascendental», op. cit, vol. l, pág. 33.

101 Cada partido tenía su propio candicato. La Unión Liberal, es decir, los cuadros superiores del Ejército y la Armada, estaban por Montpensier, que de antemano contaba con la enemiga de Napoleón y el Gobierno francés. El resultado del duelo eliminó a este candidato y evitó un posible conflicto diplomático. Los progresistas cuentan con el ex rey de Portugal, Fernando de Coburgo, quien renuncia a su candidatura. Prim propone entonces al príncipe Leopoldo Hohenzollern-Sigmaringen, al que los españoles designan humorísticamente como «Olé-Olé-si-meeligen". Francia se opone y tiene lugar el desgraciado incidente conocido como "el telegrama de Ems». El Gobierno francés no acepta una posible pinza hispano-pru- 
gran libertad de expresión, a diferencia de lo que sucede en las vísperas revolucionarias, sometida a una rígida censura, especialmente por la Ley González Bravo de 7 de marzo de 1867, la más restrictiva de toda la historia de España hasta el momento. En cambio, tras la revolución, el Gobierno Provisional da pruebas de gran liberalidad en este terreno, y raro es el día que los distintos medios de comunicación no hacen la apología de sus candidatos o la crítica de los de sus adversarios ${ }^{102}$. Naturalmente los republicanos hacen la crítica de todos y sólo se dedican a la exaltación de la República como forma de gobierno. El tema de la elección de rey superaba los planteamientos personales $y$ las preferencias por uno $u$ otro candidato. En este sentido es de destacar una interpelación del diputado republicano por Huesca, Sr. García López, en el que con motivo de los rumores aparecidos en la prensa madrileña sobre la negativa del ex Rey de Portugal, Fernando de Coburgo a aceptar el trono de España, habla del «telegrama de las calabazas» y ataca virulentamente al Gobierno por poner en almoneda la corona española ${ }^{103}$. Detrás de todo ello estaba el deseo de controlar y dirigir la revolución. De acuerdo con el candidato elegido se podría deducir qué fuerza político-social iba a protagonizar el movimiento septembrino ${ }^{104}$. En los debates constituyentes era raro el día que no se refleja en el Diario de Sesiones alguna alusión a la familia destronada o sobre el candidato de turno.

siana. Ello daría la excusa a Bismarck para declarar la guerra a Francia por la intromisión del Emperador en los asuntos alemanes. De nuevo la cuestión española va a ser tema litigioso o al menos excusa en el ámbito internacional. España, con fecha de 26 de julio de 1870, hace la declaración oficial de neutralidad en la guerra franco-prusiana. Prim ofrece la corona al general Espartero en misiva personal que le entrega Pascual Madoz. Era más un guiño hacia los viejos progresistas que una oferta auténtica. Espartero lo rechaza. Por último, la candidatura de Amadeo, hijo del Rey Galantuomo, miembro de una dinastía que se había atrevido a enfrentarse con el Papa. Como recuerda CARR, el problema es que nunca fue el candidato de todas las fuerzas que se habian confabulado para llevar a cabo la Revolución de Septiembre. Su elección tiene lugar el día 16 de noviembre de 1870 por 191 votos a favor, frente a 64 para la República, 22 para Montpensier, 8 para Espartero, 2 para Alfonso de Borbón y 1 para la Infanta Luisa Fernanda.

102 La Junta Superior Revolucionaria, en su declaración de derechos de 8 de octubre de 1868, ha formulado entre ellos el de libertad de imprenta sin legislación especial, aplicado en el decreto de Sagasta de 23 de octubre, que, por primera vez, somete los delitos de prensa a la legislación común y cuyo artículo primero decía: "Todos los ciudadanos tienen derecho a emitir libremente sus pensamientos por medio de la imprenta sin sujeción a censura ni a ningún otro requisito previon.

103 DSCC n. 58 del día 24 de abril de 1869, pág. 1341.

104 Véase en este sentido la profesora LóPEZ CORDón en Historia..., pág. 665. 


\section{c) Crisis ideológica}

Era asimismo evidente una crisis de ideas. No hay una respuesta intelectual autóctona a los serios problemas que vive el país. Fernández Almagro ha puesto de relieve la escasez de ideas en el ámbito nacional, carencia que afecta por igual a todos los partidos políticos y a todas las fuerzas sociales al margen de su ideología. Serán el mundo cultural francés e inglés mayoritariamente, los que influyen en los planteamientos de progresistas, liberales y demócratas. La influencia germánica canalizada a través de los krausistas, fue más filosófica que política, aunque gracias a ellos se puso en circulación en España un amplio repertorio de ideas propias del nuevo humanismo con gran sentido de la solidaridad. Abellán, sin embargo, realza la influencia política del krausismo como uexpresión ideológica del liberalismo de la burguesía progresista proveniente de la desamortización, que había roto - o estaba dispuesta a romper - con una Iglesia Católica demasiado anclada en el pasado, y en ese sentido representaba una cierta tendencia secularizadora» ${ }^{105}$. En la misma línea Aranguren afirma que «el krausismo español es central para entender todo el pensamiento que preparó la revolución de 1868. En efecto, éste, en la medida que existió o fue krausista o siguió a Pi y Margall. Pero Proudhon, de quien tanto aprendió $\mathrm{Pi}$ y Margall, estaba a su vez influido por el krausismo. George Gurvitch piensa que la reacción de Proudhon contra Hegel, todavía no traducido al francés, debía venirle de Ahrens... Y, por otra parte, Darimon, amigo de Proudhon, consta que fue discípulo de Krause y de Ahrens. Lo que ocurre es que Proudhon, en su reacción extrema contra la síntesis hegeliana, rechaza toda clase de "armonismos" y cree que solamente a través de la negación y de la antinomia, de la irreductibilidad aceptada y del penoso esfuerzo productivo y comunitario (...) puede llegarse a un pluralismo social (...) que no disuelve de ninguna manera la sociedad en el estado». Esta fórmula es el Principio Federalista ${ }^{106}$. Este principio, desde un punto de vista juridico, era un pacto sinalagmático en el que entidades iguales y soberanas deciden constituirse en una unidad superior. Su mejor expositor en España fue, como queda dicho, Pi y Margall. Los federales españoles pensaron siempre en términos europeos y procuraron mantener contactos con los partidos republicanos del continente. Es de destacar el punto

105 Vid. Historia crítica..., vol. IV, pág. 487.

106 López ARANGUREN, Moral y Sociedad. La moral social española en el siglo $X I X$, Madrid, 1970, pág. 143. 
de coincidencia que presenta en algunos aspectos el principio federativo proudhoniano con algún planteamiento de Krause. Así el «ideal de la humanidad" es un proceso federativo que permite a cada uno de sus miembros participar en la Razón Suprema y en el Bien. No es de extrañar que el abate Jobit haga especial hincapié en resaltar la influencia de Krause en los republicanos españoles.

Es interesante señalar cómo algunos de los primeros simpatizantes del krausismo eran los pioneros de la difusión en España de las incipientes tesis socialistas. Quizá el ejemplo más representativo es el de Ramón de la Sagra, quien ya en la temprana fecha de 1840 edita en Madrid sus "Lecciones de Economía Social", con múltiples citas tanto de Krause y Ahrens como de los primeros socialistas europeos ${ }^{107}$. Hay que tener en cuenta que el "Curso de Derecho Natural" de Ahrens ha sido traducido al español por su amigo Ruperto Navarro Zamorano ${ }^{108}$. El profesor Aranguren ve un hilo conductor desde los postulados krausistas a las ideas socialistas de un Saint Simon, Fourier y Owen. En esta línea hay que situar a Fernando Garrido, diputado en las Constituyentes, "el más activo y fecundo de los propagandistas revolucionarios", en el decir de Estévanez ${ }^{109}$, Joaquín Abreu y Sixto Cámara. Ninguno de ellos alcanzaría la originalidad y frescura de pensamiento de Ramón de la Sagra. En todos ellos ha visto el profesor Abellán una veta romántica conectada con el socialismo utópico. Para Elorza constituyen el puente entre el reformismo social y el anarquismo.

El pensamiento hegeliano encuentra en Emilio Castelar «el más destacado representante de la derecha hegeliana" según el profesor

107 Se trata de una de las personalidades más originales del pensamiento político español. Ramón de la Sagra había nacido en La Coruña el año 1798, estudiando en Saptiago Matemáticas y Medicina. Fue encarcelado por la Inquisición y marcha a Cuba, donde pone en marcha una serie de investigaciones botánicas que le darían justa fama, llegando a ser miembro del Instituto de Francia. Viajero infatigable, recorrió también los Estados Unidos y por supuesto toda Europa, cuya cultura demuestra conocer bastante bien.El año 1844 edita en Madrid la Revista de los intereses materiales y morales, de claros contenidos socialistas y siguiendo las tesis de Proudhon. Más tarde, en 1856, sufre una crisis religiosa y abraza banderas políticamente más conservadoras. Muere en 1871.

108 Véase ANDRINo HERNÁNDEZ, Manuel: "Navarro Zamorano y los orígenes del krausismo en Españan, en REP, nueva época, n. ${ }^{\circ}$ 53, Madrid, 1986, págs. 71 y ss. Analiza la personalidad de Navarro, yerno de Joaquín María López e íntimo de Sanz del Rio, según Andrino uno de los pilares básicos y también más desconocido del krausismo español.

109 Op. cit., pág. 169. 
Abellán. Por lo que respecta a la izquierda hegeliana, su cabeza visible es Francisco Pi y Margall, el más importante de los pensadores españoles de izquierda durante esta etapa. Como Castelar, también fue diputado en las Constituyentes y político en activo. Ambos llegarían a la Presidencia de la I República Española. El pensamiento de Pi está unido a las tesis asociacionistas de Althusio en su Política Methodice Digesta, a las federalistas de Proudhon y al idealismo de Hegel. Como ha destacado la profesora López Cordón, la mayor originalidad del pensamiento español de esta época se da precisamente en el ámbito del pensamiento internacionalista de los republicanos federales ${ }^{110}$. En su opinión empalman con el pacifismo de Vives y las tesis europeístas que cien años más tarde serían de uso común. En esta línea hay que destacar un importantísimo discurso pronunciado por Castelar en las Constituyentes, el día 20 de mayo de 1869, en el que expone sus ideas para la consecución de lo que él mismo llama «Los Estados Unidos de Europan"111.

Lo que sucede es que muchas de estas teorías tenían en la época en que se exponen fuertes contenidos utópicos. Se puede resumir diciendo que los tres grandes principios que defienden son: en primer lugar, el igualitarismo, entendido como la prédica de una igualdad que en el plano social conduciría al socialismo y en el plano estatal al federalismo. Naturalmente la forma política de ese estado tendría que ser la república, entendida como la fórmula omnicomprensiva de un pacto entre iguales. Este pensamiento está presente en muchas de las intervenciones parlamentarias de Pi y Margall. Esa igualdad en el plano social, conduce a la prohibición de la esclavitud y la defensa de las tesis abolicionistas con la "libertad de vientres" que encontraría su principal paladín en Rafael María de Labra112. Esa igualdad en el nivel de los estados hace que todos - grandes y pequeños - tengan los mismos derechos y por lo tanto nadie pueda imponerse por la fuerza sobre

110 El pensamiento político internacional del federalismo español, Barcelona, 1975, págs. 91 y ss.

El contacto de los líderes políticos españoles con la cultura europea es muy frecuente entre los progresistas, demócratas y republicanos; menos entre moderados, y prácticamente nulo en los unionistas. Llegó un momento, en la última década del reinado isabelino, en que Londres, París o Bruselas eran lugares habituales de residencia y exilio de los políticos españoles.

111 DSCC n. ${ }^{\circ}$ 78, pág. 2116.

112 El día 2 de abril de 1865 se constituye la Sociedad Abolicionista Española, cuyo primer presidente fue Salustiano Olózaga. En ella había hombres de todas las tendencias políticas, pero mayoritariamente republicanos. 
otros. Supone el triunfo de las tesis pacifistas, pensamiento que formaba parte del acervo cultural de la izquierda de la época.

La segunda tesis a destacar es la vigencia del llamado principio de las nacionalidades. $\mathrm{Pi}$ y Margall escribió una obra titulada precisamente Las Nacionalidades. Defendían en nombre de la igualdad el principio de autodeterminación de los pueblos, lo que implicaba la condena del imperialismo, el colonialismo y las guerras. El tercer punto a destacar es el humanitarismo. El culto a la Humanidad como un ente abstracto $y$ en el que confluían tres de las más importantes corrientes del pensamiento europeo y su correspondiente adaptación española. A saber: el romanticismo social y político de corte francés que había dado lugar a la revolución de 1848 (conviene reiterar la tesis mayoritariamente aceptada que la revolución de septiembre española es el trasunto de la europea de 1848), por otro lado el krausismo, teoría filosófica de corte alemán pero «nacionalizada» por Sanz del Río. Finalmente la influencia de un cristianismo laico que en Europa estaba abriéndose paso principalmente en los Países Bajos. Es por lo tanto la síntesis de tres pivotes fundamentales de la cultura europea -Francia, Alemania y Bélgica - que tuvieron muy pronta repercusión en círculos minoritarios españoles. Estas tres versiones de la cultura. política del momento se sintetizaron en el llamado "humanismo republicano" que Jover personifica en la obra de Pérez Galdós ${ }^{113}$ y que define como "el conjunto de mores y actitudes humanas y sociales que comparecen históricamente en la España de los dos últimos siglos, precisamente amalgamados con el tipo de mentalidad social que suele acompañar a las clases populares: generosidad frente a acumulación, solidaridad frente a individualismo, sentido espontáneo e intuitivo de la moral frente a legalismos formalistas, respeto del ven-

113 Desde este planteamiento, la obra literaria del novelista canario es de una importancia extraordinaria y sus famosos Episodios Nacionales un auténtico manantial de datos históricos. Don Antonio MAURA recuerda en el Boletín de la Academia de la Lengua correspondiente al mes de abril de 1920, con motivo de la muerte de Galdós (4 de enero de 1920), que fue «divulgador de la historia política de la patria de aquella épocan. Hay una gran valor testimonial en toda su obra; abundancia de datos históricos y retratos de personas y paisajes, cuyo conocimiento resulta indispensable para el conocimiento de la época. Julio RodRiguez PuÉrtolas ha insistido en el papel de fiel notario de la sociedad de su época que lleva a cabo el escritor en su obra Galdós: Burguesía y revolución, Madrid, 1975. Para Federico Carlos SAINZ DE ROBLES, prologuista de los Episodios Nacionales y autor de una Introducción que incluye una amplisima y detallada biografía de Galdós, estamos ante el caso de un RECREADOR excepcional de personajes históricos del siglo XIX (op. cit, vol. III, pág. 1414). 
cido en razón de su última condición humana, frente a su trascendentalización maniquea con miras al aniquilamienton" ${ }^{114}$.

En el orden práctico, aunque no se consiguió todo lo planteado, hay que reconocer que hubo avances considerables en el campo de la reforma penal y penitenciaria, la política asistencial, redención de la esclavitud etc. Aunque siguieron subsistentes los "consumos" y la llamada "contribución de sangre». Posiblemente la vigencia de las "quintas" sea a nivel popular la gran frustración de la Revolución. Estévanez afirma que "el error del 68 fue no implantar la república después de Alcolea" y no satisfacer el clamor popular de la supresión de quintas.

En el terreno de las utopias que acompañan a todo movimiento revolucionario se dio el caso de que estaban perfectamente diseñadas desde el punto de vista intelectual, pero lamentablemente faltaba la fuerza social suficiente para llevarla a cabo. Como dice Manheinn, en toda revolución hay que tener en cuenta los componentes utópicos que conlleva. Los grandes mitos del sexenio fueron el federalismo, el republicanismo, el humanismo popular y la supresión de consumos y quintas. Todos ellos se compendiaban en la utopía por excelencia: LA UTOPÍA REPUBLICANA, que, como recuerda Jutglar pretendió "conciliar los intereses antagónicos y evitar los conflictos de clase, sin suprimir las causas de la desigualdad de las mismas» 115 . Pues bien, en el caso español es claro que ninguno de ellos llegó a transformarse en "iideologia» de acuerdo con la terminología utilizada por el sociólogo alemán ${ }^{116}$.

Por último también la derecha extrema de España, políticamente representada por el partido carlista o tradicionalista, tampoco fue ajena a la influencia del pensamiento europeo. Carlistas y los llamados neocatólicos que, como los calificaba Ruiz Zorrilla, "son más realistas que el rey y más papistas que el papa»117, constituyeron en un

\footnotetext{
114 JoVER, «Introducción», tomo XXXIV, Historia de España de MENÉNDEZ PIDAL, pág. CXVI.

115 En Revista de Occidente n. ${ }^{\circ}$ 67, año 1968, pág. 141.

116 Desde este punto de vista y a nivel de alta política, las tres grandes utopias del pensamiento internacionalista fueron:

1. La República Federal española.

2. Los Estados Unidos de Iberia. La llamada Unión Ibérica.

3. Los Estados Unidos Europeos.

117 DSCC, pág. 182. En la misma sesión les acusa publicamente de «haber vendido manuscritos y códices por arrobas".
} 
primer momento un frente único cuya máxima figura intelectual fue Cándido Nocedal junto a Aparisi Guijarro ${ }^{118}$. Reivindican el foralismo y se apoyan en un romanticismo de signo alemán que hace especial hincapié en el nacionalismo de corte territorial y la potenciación de las culturas autónomas. Desde el punto de vista de la organización política podría aplicársele el modelo que Juan Linz llama "democracia consociacional"', directamente inspirada en las tesis althusianas. Curiosamente coinciden con los republicanos españoles en sus tendencias federalistas. $Y$ es que, como ha destacado Vedel, a partir de Tocqueville el federalismo se desarrolla en dos líneas perfectamente diferenciadas. El federalismo como medio de libertad interior, que fue asumido desde el principio por el pensamiento político de la derecha, especialmente Taine y Maurras. De otro el federalismo como instrumento para conseguir la paz externa. Es el federalismo internacionalista, asumido por la izquierda tanto en sus corrientes socialistas (caso Proudhon), como anarquistas (Bakunin y Propotkin)119. Por otra parte, no pueden dejarse de lado los fundamentos morales del federalismo que puso de relieve en su día el profesor Berger.

Pero la impronta intelectual más importante en cuanto a sus realizaciones prácticas fue la doctrinaria. La corriente política que según Ortega y Gasset habia engendrado el pensamiento político más importante de la Europa del XIX. Se lamentaba el filósofo madrileño que la ignorancia del mismo corría paralela a su magnitud. Un discípulo de Ortega, recientemente fallecido, don Luis Diez del Corral define el doctrinarismo "como un movimiento de contornos poco precisos, que puso las bases del sistema parlamentario continental, pero cuya plena madurez se llegó a producir por concesiones hechas al principio monárquico y a un sentido aristocrático burgués de la sociedad» ${ }^{120}$.

El doctrinarismo se desarrolla en España durante los años treinta e influye decisivamente en el Estatuto de 1834 y de modo especial en la Constitución de 1945, piedra angular del constitucionalismo isabelino y, en opinión de Díez del Corral, «la aportación más original de España a la historia de las formas constitucionales»121. La labor de los hombres del 68 será precisamente acabar con este texto y sustituirlo por el de 1869. Esta Constitución va a ser el trasunto hispánico de las

118 Era diputado tradicionalista por Bilbao. Su acta fue admitida sin dis-

cusión el 9 de marzo de 1869, DSCC n..$^{\circ} 22$, pág. 399.

119 Véase la obra colectiva El Federalismo, Tecnos, Madrid, 1965.

120 Op. cit., pág. 15

121 İdem, pág. 21. 
tesis de Royer-Collard, Guizot, Montesquieu y Constant. Sus autores, muy versados en la última moda de la cultura europea, recogen sus tesis, las incorporan al derecho público español, pero como advierte el autor que seguimos, llevan a cabo un proceso de nacionalización de las mismas. Alcalá Galiano, Martínez de la Rosa, Javier de Burgos, Donoso y Cánovas serán los grandes doctrinarios españoles. Por influencia krausista los republicanos de 1869 atacarán a la Constitución de la Gloriosa tachándola de doctrinaria. El Diario de Sesiones recoge espléndidos debates en este sentido. Todos ellos conectados con el tema de la forma de gobierno. Es frecuente aludir a la dialéctica entre la "idea republicanan y la "idea doctrinaria", usándose esta última expresión para los defensores de la forma monárquica de gobierno. Moret el día 8 de abril, en una gran confrontación parlamentaria con Castelar rechaza este calificativo para el proyecto de Constitución que acaba de presentar ${ }^{122}$. En la sesión del día 18 de mayo de 1869 , cuando se discutían los artículos relativos a la forma de gobierno, de nuevo sale a colación el tema de la confrontación entre la «idea democrática» y la "doctrinaria». Sánchez Ruano es uno más de los diputados republicanos que tachan de doctrinaria la constitución del $69^{123}$. Becerra en nombre de la mayoría afirma que la constitución no es doctrinaria, aunque si de "transacción»124. El tema es una constante siempre que salga a relucir la forma de gobierno, y la prensa contribuye a mantener viva la polémica. Así, el diario La Discusión, en un editorial del día 31 de marzo de 1869, recién presentado el proyecto constitucional, lo rechaza en base a "su carácter doctrinario". El único diputado que mantiene con gallardía su posición doctrinaria es Cánovas del Castillo. En una brillante intervención que tiene lugar el dia 12 de abril de 1869, el diputado unionista habla del poder armónico, defiende el sufragio censitario y diseña ante la Cámara el tipo de monarquía que se vería plasmado en la Constitución de 1876. Termina haciendo un gran elogio de Stuart Mill. Sus palabras calan en un auditorio que no comparte sus planteamientos pero respeta la elegancia de su exposición, no exenta de gallardía y firmeza. Como es natural, si las constituyentes del 69 habían de eliminar la Constitución doctrinaria del 45 , la de 1876 tendería puentes hacia el pasado y situaría sus anclajes precisamente en la Constitución doctrinaria por excelencia. Se vuelve a la teoría de la Constitución Interna, tan cara a los doctrinarios y de evidente influjo jovellanista. En el debate preconstituyente y a partir del

\footnotetext{
122 DSCC n. ${ }^{\circ} 44$, pág. 908.

123 DSCC, pág. 858.

124 DSCC, pág. 1017.
} 
Manifiesto de los Cimbrios de 12 de noviembre de 1868 se afirma ya con rotundidad que «la forma monárquica es la forma que imponen con irresistible fuerza la consolidación de la libertad y la exigencias de la revolución". Parece como si las tesis doctrinarias a favor del poder moderador de la Corona - lo que implicaba la existencia y reconocimiento de la Monarquía - hubieran calado profundamente en los protagonistas de la revolución.

En el Manifiesto del Gobierno de 25 de octubre de 1868 se dice que «no han confundido, a pesar de lo fácil que era en horas de perturbación apasionada, las personas con las cosas, ni el desprestigio de una dinastía con la más alta magistratura que simbolizan. Es un lenguaje que recuerda mucho al utilizado por los doctrinarios. De ahí que para matizar y señalar diferencias los demócratas, con Rivero a la cabeza, exponen su teoría de la "monarquía popular»: la que nace del derecho de los pueblos, la que consagra el sufragio universal, la que simboliza la soberanía de la nación, la que consolida y lleva consigo todas las libertades públicas, la que personifica en fin, los derechos de los ciudadanos, superiores a todas las instituciones y todos los poderes. Es la monarquía que destruye radicalmente el derecho divino y la supremacía de una familia sobre la Nación; la monarquía rodeada de instituciones democráticas, la monarquía popular. Sobre la importancia de este debate desde el punto de vista ideológico, baste reiterar que fue, junto con el tema de la unidad religiosa, el más importante de las Constituyentes ${ }^{125}$.

\section{d) Crisis de la clase política}

Había también una crisis de la clase política propiamente dicha. Crisis que estaba presente en los albores de la revolución al dividirse el país entre partidarios de los Borbones y enemigos de los mismos, pero que, expulsada la reina, se va a dejar sentir también entre las fuerzas que han dirigido la revolución. Después de septiembre las fuerzas se dividen por el tema de la forma de gobierno, como se ha indicado. La mayoria se hace un bloque compacto, gracias a la inteligencia de Prim, que suma a las fuerzas del pacto de Ostende (demócratas y pro-

125 El profesoir Antonio María CALERo, tan prematuramente desaparecido, recogió en un volumen los discursos parlamentarios que sobre la monarquía se pronunciaron en las Cortes de 1869. Véase su Monarquia y Democracia en las Cortes de 1869, CEC, Madrid, 1987. 
gresistas), los unionistas, contando con la colaboración de Dulce y Serrano. Gracias a ello se consigue "nacionalizar" la revolución y ampliar su base, incluyendo los sectores mesocráticos del país. Nadie, sin embargo, cuenta con el proletariado que ya está empezando a configurarse en nuestra patria, pero que aún no está organizado políticamente. García Cortázar y González Vesga creen que "la incorporación de los militares confiere al movimiento una dualidad ideológica que se manifestará en los vaivenes de la etapa revolucionaria, entre el monarquismo moderado de los altos oficiales y el democratismo de las Juntas, expresión de los intereses de la pequeña burguesía, los artesanos y el proletariado" ${ }^{126}$.

Prim es la figura indiscutible dentro del partido progresista, que "habia sido la formación política más importante de la izquierda española durante la época isabelina", como afirma Francisco Cánovas ${ }^{127}$, partido que hasta la incorporación de el Marqués de los Castillejos arrastraba una existencia lánguida, ya que, como afirma muy irónicamente Estévanez, "los progresistas progresan con una lentitud maravillosa" ${ }^{128}$. Su liderazgo se acrecienta día tras día, máxime después de la renuncia vía telegrama que hace Espartero de su acta de diputado por Logroño y Zaragoza y que supone la total retirada política del Conde de Luchana ${ }^{129}$. De ahí que a nadie le extrañe su negativa a aceptar la corona española. La otra posible competencia en el orden civil, dentro del partido, por parte de Salustiano Olózaga, está perfectamente controlada. Pero Prim no es sólo el héroe de la Revolución, sino un militar al que respetan los civiles y también el resto de sus compañeros de armas militantes de la Unión Liberal, capitaneados por Serrano y quien a título personal llevara a cabo una función importantísima: poner de acuerdo a la variopinta gama de personalidades que se han unido momentáneamente para derribar la monarquía. El Duque de la Torre, sucesor de O'Donnell al frente de la Unión Liberal (plataforma política que aglutina to más avanzado del viejo moderantismo y lo más conservador del progresismol, será de esta forma el aglutinador de un mosaico de personajes civiles y militares de ambiciones

126 Historia de España, págs. 436-7.

127 Francisco CÁNOVAS SÁnCHEZ: "Los partidos políticos", tomo XXXIV, Historia de España de Menéndez Pidal, págs. 373 a 500 . La cita precedente, en la pág. 411. El estudio sobre el Partido Moderado, que fue el tema de su tesis doctoral, está publicado por el CEC.

128 Op. cit., pág. 152.

129 El acto de renuncia tiene lugar el día 23 de febrero de 1869. Véase DSCC n. ${ }^{\circ} 11$, pág. 143. 
manifiestas y contrapuestas. Ellos son conscientes de la necesidad de unión al menos hasta que el texto constitucional esté aprobado. Es una disciplina que se acepta más o menos voluntariamente por parte de todos y a la que dan forma los miembros militares de la conspiración. No puede olvidarse que los grandes protagonistas del 68 son los representantes del ejército. En este aspecto se continúa la pauta ya iniciada en épocas anteriores por la que serán militares los dirigentes de los partidos políticos españoles tanto conservadores como progresistas. Ellos van a marcar las pautas del modelo político a seguir ${ }^{130}$. Tanto en el seno del partido progresista como, aún en mayor cantidad, en la Unión Liberal abundan los cuadros militares. Alonso Baquer ve "una constante conservadora" en el talante de los generales que destronaron a la Reina. El más avanzado de ellos, el General Prim asume, como ha señalado Seco Serrano, el difícil papel de "fijar" la revolución y garantizar el nuevo orden político que se establecía. Era el único con auténtica visión de estadista, de ahí que estuviera dispuesto a sacrificar incluso sus proclividades republicanas para mantener la cohesión del "frente amplio" que inicia su actuación en Cádiz y termina con la llegada de Amadeo. Era consciente que el precio a pagar era muy caro: había que prescindir de la República. Seco afirma que Prim sueña con "una democracia coronada" dirigida por un "Rey Soldado" rodeado de civiles. El poder era más militar que civil. Unos generales expulsan a la reina. Los mismos traen una nueva dinastía a la que "un pleito en el seno de la familia militar - la crisis de los artilleros-" servirá de excusa para liquidar la monarquía saboyana131. El papel de la burguesía va a consistir en inspirar la acción de los militares y éstos a su vez se prestan al juego dejándose utilizar. En el ambiente actúa como creencia colectiva el concepto de seguridad tan caro a la mentalidad burguesa. Este ambiente llega a penetrar incluso en las filas republicanas. Castelar postulaba una República «con mucha infantería, mucha caballería y sobre todo mucha guardia civil».

En el partido demócrata la crisis se plantea con el tema de la forma de gobierno. Se produce la división entre republicanos, en su doble vertiente federalista (mayoritaria) y la unitaria, y los cimbrios, grupo escindido al aceptar la monarquia. Fueron la fuerza intelectual del bloque de poder que sale de la revolución. La mayor parte de ellos aca-

130 EstéVANEz señala que ninguno de ellos dejaron memoria escrita de su actuación.

131 Seco Serrano, Carlos: Militarismo y civilismo en la España Contemporánea, Madrid, 1984, pág. 143. 
barian participando en la Restauración. Surgido en el año 1849, miraban con simpatía las nuevas corrientes socialistas surgidas en Inglaterra y Francia y se decantaron por la República. De ahí la sorpresa de la aparición de los Cimbrios, accidentalistas en el tema de la forma de gobierno pero fundamentalmente antidinásticos. Su líder natural era Nicolás María Rivero, político sevillano uenemigo del militarismo, pero más enemigo aún del régimen, transige con las intentonas de Prim y hace la vista gorda cuando Pierrad, Contreras e Hidalgo sublevan a los artilleros de San Gil y traen la última sombra de la reacción: el ministerio González Bravo. Y mientras la reacción destierra a Serrano, a Dulce, a Zavala, a Córdoba, a Serrano Bedoya, a Echagüe, a Caballero de Rodas; Rivero con la Junta Revolucionaria se prepara a entrar en escena. Alcolea es el triunfo bullanguero del sable, de los vitores y de las charangas; pero el triunfo de la Revolución, la implantación de la soberanía popular, la consolidación de los derechos individuales, la europeización política de España, no son Prim, ni Serrano, ni Topete; sino Rivero, Aguirre, Figueras, los conspicuos de la Junta Central Suprema, que ha de ser antesala de las próximas Constituyentes»» ${ }^{132}$.

En las filas del carlismo o tradicionalismo tiene lugar un fenómeno muy curioso. La revolución y el destronamiento de Isabel II sirven para reforzar un partido que ha vivido las incidencias de unas guerras saldadas en fracaso militar y unos sucesos familiares que terminan en problemas dinásticos y políticos. Cuando muere en Trieste el año 1861, el Conde de Montemolín (Carlos VI en la dinastía carlista) su padre Carlos María Isidro, que le sobrevive, recoge la antorcha hasta el año 1865 que la traslada a su otro hijo Juan de Borbón y Braganza, quien, para mayor indignación de sus súbditos, se proclama liberal y reconoce a su prima Isabel II como Reina de España. Tras un desconcierto imaginable, el año 1868 don Juan renuncia los derechos dinásticos a favor de su hijo Carlos, el futuro Carlos VII.

El año 1864 la Princesa de Beira, viuda de Carlos María Isidro (Carlos V), dirige una "Carta a los españoles" cuya autoría material se debe al Obispo Caixal y a D. Pedro La Hoz, en la que se marcan las nuevas directrices de actuación para el Partido Carlista a la vista de una revolución que está en el horizonte de todos y en la que lo único seguro es la inminente caída de la dinastía reinante. Cuando ésta se produce, el carlismo levanta el vuelo y recoge nuevo impulso. Aróstegui

132 Cristóbal dE CASTRO: Estudio Biográfico del Exmo. Sr. Don Nicolás María Rivero, Congreso de los Diputados, Madrid, 1915, pág. 21. 
ha destacado que «durante el sexenio hay un desplazamiento hacia el carlismo de una masa importante de los más conservadores estratos de la burguesía liberal, de la Iglesia apaciguada desde el Concordato de 1851 y de los grados medios del ejército» ${ }^{133}$.

Desde el punto de vista ideológico, sus principales cabezas fueron Aparisi, Vildosola, Llauder, Tejado y Manterola. De ellos, el único pensador con cierta originalidad fue el primero. Los demás carecían de relieve, lo que no significa que no jugaran un papel importante - caso de Manterola - en las Constituyentes. Pero el fracaso de sus ideas y aspiraciones fue también el principio de su decadencia como grupo político. Pasado el momento floreciente de las Cortes de 1869, vuelven a un discreto lugar en el escenario político español. En lo sucesivo serán una formación testimonial, que sólo vuelve a tener cierta importancia política en los prolegómenos de la guerra civil española de 1936. Al "legitimismo" le sucede igual que a sus homónimos europeos, con los que coincide en su incapacidad para crear unas alternativas ideológicas viables frente a las realizaciones burguesas inspiradas por el liberalismo.

\section{e) Crisis social y económica}

María Victoria López Cordón, al referirse a la revolución, la designa como "la brusca sacudida" que conmociona los cimientos de la sociedad de la época, resaltando la importancia decisiva que en ella tienen los planteamientos económicos. La crisis de subsistencias de $1866^{134}$, la epidemia de cólera de 1865 y la hambruna de 1868 , son el caldo de cultivo para una agitación social que en algunas ocasiones va a tener una traducción política. Tal es el caso de las revueltas andaluzas. Nicolás Sánchez Albornoz recoge una coplilla popular que expresa el sentimiento de los desfavorecidos:

Año de sesenta y ocho,

Año de calamidades;

$Y$ para mayor desdicha,

nos han puesto los rurales ${ }^{135}$.

133 Julio Aróstegul, en Historia de España de Menéndez PIDAL, tomo XXXIV: "El carlismo y la guerra civil», págs. 71 y ss. La cita precedente, en la pág. 133.

134 Para SANCHEZ ALBORNOZ, "la catástrofe del 66 fue la madre de la revolución del 68", Revista de Occidente n. ${ }^{\circ} 67$, pág. 51.

135 Ídem, ídem, pág. 41. 
La crisis es tanto más grave cuanto que el modelo económico capitalista se está aplicando sobre estructuras socioeconómicas muy tradicionales que no pueden soportar tranquilamente su incidencia. La crisis económica se va a reflejar especialmente en los ferrocarriles, lo que lleva aparejado el inicio de la desindustrialización del país y a su vez incide sobre la crisis financiera del Estado, que desde 1866 está prácticamente en bancarrota, como han destacado Tortella y Nadal. Ello va a tener importantes repercusiones políticas, ya que los sectores afectados se desenganchan de un régimen que ya no les garantiza su status y empiezan a ver con buenos ojos la revolución, hasta entonces sólo pregonada en los periódicos. Muchos de los futuros dirigentes, como por ejemplo Madoz y Figuerola, forman parte del Consejo de Administración de las grandes empresas surgidas al calor del trono isabelino, $y$ ahora se encuentran decepcionados y buscan una solución política de recambio porque la actual ya está agotada como modelo económico. Esto por lo que afecta a las clases altas. Confían en que la revolución solucione sus problemas. Lo que ignoran son las contradicciones internas en el mismo nivel de clase. Cuando se quiere aplicar el librecambismo, la revolución empieza a jugarse su futuro desde las mismas clases sociales que la han dirigido. La burguesía catalana, abiertamente proteccionista, vive un paulatino enfriamiento hacia la revolución y un desinterés cada día mayor hacia la misma. El asesinato de Prim complica aún más las cosas. La doble existencia de un eje económico en Barcelona frente a un eje político en Madrid, permitirá a la burguesía catalana ensayar un intento de República, con muchos apellidos catalanes entre sus dirigentes, para regresar con más ímpetu en la restauración alfonsina de 1874, cuando observen que la fórmula republicana no es la solución a sus problemas. Cataluña va a jugar un importantísimo papel político en el último tercio del siglo $\mathrm{XIX}$, tanto que puede hasta cambiar el signo de los pronunciamientos y las revoluciones que tienen lugar en la península. Pronunciamiento de carácter progresista con el catalán Juan Prim a la cabeza, ensayo republicano federalista con Figueras y $\mathrm{Pi}$ y Margall, establecimiento de las bases doctrinales del federalismo en la obra de Valentí Almirall i Llozer y modelos de pronunciamientos conservadores en el caso de Martínez Campos y Primo de Rivera. A pesar de todo ello "la política económica del 68 significa el esfuerzo legislativo y administrativo más coherente para implantar el liberalismo económico que se haya dado nunca en España», en opinión de Tortella ${ }^{136}$.

136 Los orígenes del capitalismo en España, Madrid, 1973, pág. 296. 
El ajuste de la política monetaria se lleva a cabo en virtud de un Decreto de 19 de octubre de 1868, que establece la peseta, moneda de origen catalán, como la nueva unidad monetaria de la Monarquía. El profesor Carr niega que fueran razones económicas las que acaban con el sexenio. En su opinión, la política de Figuerola estaba en condiciones de proporcionar una buena base para el despegue económico. En cambio, el colapso en la política de orden público y la incapacidad para dar respuesta a las demandas sociales más elementales, daría la puntilla al régimen de septiembre.

El pueblo se va apartando poco a poco de la revolución con la que ha soñado. Se mantiene el resentimiento popular en el tema de las quintas, que siguen vigentes. La burguesía gobernante todo lo que hace en este tema es rebajar la cuota de los 8.000 reales a los 6.000 para poder librarse del servicio militar. La decepción popular es cada día mayor. Por eso es en esta época cuando se desarrolla el movimiento obrero y esa modalidad típicamente hispánica que es el anarquismo. Las clases medias se alarman y acaban entregándose en manos de la burguesía. La Restauración, como capítulo que cierra la Revolución, está ya a la vista. La posibilidad de haber evitado esta frustración de los sectores sociales más humildes hubiera sido poner en marcha las posibilidades que contenía la Constitución del 69 para mejorar las condiciones sociales hasta un límite compatible con la política económica liberal que la recorría. Pero no hubo tiempo ni posibilidad. La función transformadora se quedó inédita. Las clases sociales más privilegiadas vieron consolidado su planteamiento de burguesía conservadora. Las más humildes trasladaron al campo de la utopía los sueños que habían puesto en la revolución y a partir de este momento toman conciencia de clase y no volverán a colaborar con la burguesía en ningún proyecto político, hasta su participación en el bienio Azaña en 1931. La Constitución, que tan magnífico despliegue legislativo llevó a cabo en el tema de los derechos y libertades individuales, fue extraordinariamente parca en los de contenido social, que por otra parte apenas contempla, salvo en el ámbito del derecho de reunión y asociación.

En un grueso volumen de 1240 páginas editado por el Congreso de los Diputados el año 1987, para exponer la historia de la Legislación social en España, son prácticamente nulas las aprobadas durante la vigencia de la Constitución del $69^{137}$. A los más desfavorecidos

137 Quizá por su contenido social, la más importante fuera la Ley de 4 de julio de 1870, de abolición de la esclavitud y emancipación de los esclavos en Cuba 
sólo les quedaba soñar con el advenimiento de un reinado milenario sobre la tierra, típico producto de la mentalidad utópica ${ }^{138}$. La revolución, que se ha puesto en marcha como un amplio movimiento de masas que alientan y respaldan a las elites militares, serían más tarde abandonados a su suerte.

\section{LA CONSTITUCIÓN}

En la Constitución se resumen y recogen todas las variables de esta cultura política que comentamos. También todas sus contradicciones internas. Si el concepto de revolución puede reflejar los valores ideológicos del sexenio a la perfección, el de constitución pretende marcar las pautas normativas para esa nueva sociedad a la que la revolución aspira. De ahí que junto a la función ideológica haya que situar como corolario lógico la función política, jurídica y organizativa que el texto representa. Son prácticamente las mismas que actúan en el concepto revolución, pero ello es debido a que una - la constitución- es la consecuencia de la otra, de ahí que hayan de considerarse de forma correlativa.

Íntimamente ligado a la crítica de la revolución está la negativa a una Constitución que la minoría no considera aceptable. Era lógico. En la escala de valores, si se rechaza el contenido revolucionario, dificilmente podría aceptarse el continente jurídico en que se pretendía normativizar. Figueras la califica de "doctrinaria», expresión que en el lenguaje de la época era sinónimo de la más pura reacción y el summum de la moderación. De su discurso se desprende la idea de una constitución que con terminología actual llamaríamos «semántica» en el sentido expuesto por Loewenstein ${ }^{139}$. Carente de contenidos y con-

y Puerto Rico, publicada en la Gaceta del día 6 de julio de 1870; el art. 556 del Código Penal, que por Ley de 17 de junio de 1870, publicada en la Gaceta del día 3 de agosto, impone la pena de arresto mayor a los que maquinen para alterar - encareciendo o abaratando excesivamente - el precio (sic) del trabajo, y la Ley de 24 de julio de 1873, publicada en la Gaceta del 28 de julio, sobre las condiciones de trabajo en las fábricas, talleres y minas. Véase la obra colectiva La Legislación social en la Historia de España. De la revolución liberal a 1936, dirigida por Antonio MARtín VALVERDE, Congreso de los Diputados, Madrid, 1987. 1240 págs.

138 MANNHEIM aplica a este tipo de mentalidad social el nombre de "quilianismo" y en su opinión supone una espiritualización de la acción pòlítica, al estar impregnado de tensiones espiritules, humanitarias y religiosas. Véase Ideologia y Utopía, pág. 283.

139 DSCC, págs. 869 y ss. 
tradictoria en sus términos, ya que pretende ser la bandera de la revolución que expulsó a la dinastía y se proclama monárquica. Se vuelve al tema sempiterno de la forma de gobierno que servirá a lo largo de todo el debate como la mejor prueba de la traición al espíritu revolucionario (un espíritu que sirve para expulsar a los reyes, y los mismos dirigentes que la han llevado a cabo, están buscando un reyl. Se ha hecho una constitución para un rey, no para un país y mucho menos para una revolución. Castelar también destacaría la falta de sintonía entre la Constitución y la Revolución y critica la "búsqueda vergonzante y humillante de un rey". Hay, según el gran tribuno, un divorcio evidente entre las ideas revolucionarias y los hechos que le siguen. No es lógico en su opinión aceptar «el principio democrático" y no aceptar sus consecuencias. Este será uno de los caballos de batalla ideológicos de las Cortes.

Un sector importante de ellas - fundamentalmente la minoria republicana - entiende e identifica principio democrático con forma republicana de gobierno, reservando para la monarquía el principio doctrinario. Serán los dos grandes y opuesto puntos de vista del debate doctrinal. Moret actúa como el gran teórico del doctrinarismo desde las filas de la mayoría, entendiendo por tal aquel sistema que sirve de garantía de la libertad y los derechos, al margen de la forma de gobierno ${ }^{140}$. En una hábil finta dialéctica hace de la Constitución el trasunto normativo de la revolución. El texto que, en nombre de la Comisión, ofrece en su intervención del 24 de febrero de 1869 lleva en su articulado los sueños de la revolución: "Hay pues que decirle al pueblo español: levántate y marcha; vamos a aligerarte la carga; hoy te hemos creado ciudadano por medio de una revolución política; mañana te haremos rico por medio de una revolución económica; y más adelante, por medio de esta completa revolución social, te haremos hombre al nivel de tus hermanos de Europa" ${ }^{141}$. El hábil orador gaditano mezcla en esta intervención la intencionalidad política que justifica la revolución con la utopía de un mundo mejor. Parece resonar en el hemiciclo el "justos y benéficos" que los constituyentes de Cádiz prometían a los españoles por el simple hecho de contar con una Constitución.

El Doctor Mata, también miembro de la Comisión Constitucional, propugna una constitución de consenso, pero advierte sobre la difi- 
cultad de hacer un texto "a gusto del consumidor". De ahi vienen, en su opinión, las críticas al texto, porque cada grupo querría una constitución a su estilo. Propugna una constitución de consenso, lo que no pasa de ser una muestra de buena voluntad, ya que a la hora de constituirse la Comisión que había de redactar el Proyecto, quedaron excluidos los republicanos y los carlistas. Es decir, se constituye una comisión gubernamental integrada exclusivamente por miembros de la mayoría - progresistas, unionistas y demócratas-. En su intervención propugna también su deseo de hacer una Constitución breve y sintética, de gran claridad y que no se preste a interpretaciones. Parece como si el eximio doctor pretendiera llevar al texto el aforismo romano de "in claris non fit interpretatio", y en cuanto a la brevedad postulada pone de manifiesto la atracción que en aquella época ejercía la Constitución Norteamericana - sólo siete artículos - en todas las mentes progresistas europeas ${ }^{142}$. Para Figueras, en cambio, la Constitución ha nacido muerta. Llega a calificarla de "constitución aborto". También desde la oposición moderada, Cánovas del Castillo la critica, pero desde una actitud más dialogante. Afirma que la Constitución es arte de estado más que Ciencia Política, y parafraseando a Maculay dice que la "política es el arte del compromiso", la ciencia de las transacciones entre intereses contrapuestos. Se vislumbra con meridiana claridad la atmósfera constitucional y política que va a presidir la Restauración, y la tendencia, por otra parte típica de la mentalidad conservadora de que una buena administración es mejor que la mejor constitución. Es el sueño del "burocratismo», de lo que Manheinn llama la «mentalidad administrativa" que hace de las grandes opciones políticas, asuntos rutinarios de Estado.

Ríos Rosas se encargaría, en nombre de la Comisión, de darle la réplica al político malagueño. La base de su intervención es para reiterar el contenido político y democrático del texto, que en su opinión se ajusta a los postulados de Cádiz. Al final, entre unos y otros la sacaron adelante, ante la indiferencia de un pueblo que no podía entender que los políticos estuvieran enzarzados en floridos debates, mientras los grandes temas de la revolución seguían pendientes de resolver. Un personaje de Galdós, comentando con otro la trascendencia de la aper-

142 DSCC, pág. 881.

La influencia noerteamericana no se limitaba a la brevedad en el texto. Para los republicanos - en cuyas filas había militado con anterioridad el Dr. Mata - el principal atractivo del texto americano era la forma republicana de gobierno y además con el calificativo de federal. 
tura de las Constituyentes el día 11 de febrero, afirma textualmente: "Dicen que vais a hacer una Constitución. Para qué. Copiad una de las anteriores" 143 . La cita revela la indiferencia con que el pueblo soberano sigue un debate constitucional que se va haciendo excesivamente largo. Algunos líderes políticos se dan cuenta de ello y deciden abreviar el íter constitucional. Se prolongan las sesiones y se imprime un ritmo más acelerado al debate del Proyecto Constitucional. En el ánimo del pueblo, en el conjunto de creencias que forman el sustrato de su cultura política, faltaba el "sentimiento constitucional" la identificación con el texto. Para ellos el tema determinante seguía siendo el de "Revolución".

Sin embargo, a pesar de estas opiniones, más "sentidas" que "razonadas" el texto del 69 ha pasado a la historia del constitucionalismo como uno de los más importantes de nuestra Historia y de los pocos que aguantan un análisis comparado con los de cualquier otro tiempo y país. Incluso en algunas cuestiones superior y más avanzado que muchos otros.

Desde el punto de vista de su estructura, la Constitución de 1869 es desde el plano formal un texto largo, extenso, con 112 artículos y dos transitorias que le hacen ocupar el tercer puesto en la historia patria, tras Cádiz y la constitución vigente. Para Fernández Segado, estamos ante un texto muy prolijo en su parte dogmática con «bastantes preceptos casuistas, detallistas y un tanto superfluos a veces" ${ }^{144}$. Siguiendo a este autor, estamos ante una "Constitución completa y sistemática». En sus once títulos aborda todas las cuestiones propias de un texto constitucional ${ }^{145}$. Finalmente, es una constitución rígida, que dificulta su reforma al exigir un procedimiento de doble revisión, des-

143 En “España sin Rey», Episodios Nacionales, vol. III, pág. 789.

144 Las Constituciones Históricas Españolas, pág. 291.

145 La denominación de los títulos y el articulado que comprende es la siguiente:

Título Primero: “De los españoles y sus derechos». Arts. 1-31.

Título II.»De los poderes públicos». Arts. 32-37.

Título III. "Del poder legislativo». Arts. 38-66.

Título IV. "Del Rey». Arts. 67-76.

Título V. "De la sucesión a la Corona y de la Regencia del Reino". Arts. 77-86.

Título VI. "De los Ministros». Arts. 87-90.

Titulo VII. "Del Poder Judicial». Arts. 91-98.

Título VIII. "De las Diputaciones Provinciales y Ayuntamientos". Art. 99.

Título IX. "De las contribuciones y de la fuerza pública». Arts. 100-107.

Título X. "De las provincias de Ultramar". Arts. 108-109.

Título XI. «De la reforma de la Constitución». Arts. 110-112: 
tacando el hecho de que las nuevas Cámaras tendrían carácter de constituyentes, no pudiendo ser disueltas, aunque este carácter afectará exclusivamente a la deliberación objeto de la reforma. Como es sabido, no hubo lugar. La vigencia de la constitución fue bastante problemática, como afirma Tomás y Valiente, pasando por diversos períodos. Conviene destacar que a pesar de la identificación Sexenio=Constitución que suele hacerse, durante este tiempo la Constitución no siempre se aplicó. Es en el reinado de Amadeo I el único momento en que estuvo plenamente vigente y se cumplió escrupulosamente, empezando por el propio monarca, que fiel a ella y consecuente con los principios que contenía, no tuvo inconveniente en renunciar a la Corona.

Desde el punto de vista de la función jurídica, el texto del 69, en su condición de pilar del resto del ordenamiento jurídico, puso en marcha un amplio despliegue de desarrollo normativo, alguna de cuyas normas han llegado a nuestros días. Los legisladores del sexenio tenían prisa por llevar a los Códigos los grandes principios constitucionales que contenía el texto. La legislación de desarrollo de la Constitución es ciertamente ejemplar desde la óptica de un estado de derecho que responde a los principios de un liberalismo avanzado. Puso en marcha un nuevo orden jurídico al que, de acuerdo con los principios de jerarquía normativa y primacía constitucional, tenía que someterse el resto del ordenamiento jurídico. Este nuevo orden jurídico respondía a los planteamientos de la técnica del Estado de Derecho. Unas normas jurídicas que afectan por igual al gobernante y al gobernado, utilizando la terminología de Duguit, que se basan en el principio de generalidad y excluyen cualquier posible privilegio. Un texto lleno de respeto a la norma, que pretende hacer realidad la famosa afirmación de Montesquieu: «legum servi sumus, ut liberi esse possumus».

En cuanto a la función legitimadora, la Constitución se presentaba como la mejor tarjera de visita del nuevo régimen. Era un texto avanzado pero que no podía provocar recelos en los restantes pueblos de Europa. No puede olvidarse que desde el punto de vista internacional, la revolución septembrina había planteado recelos por el temor de que abriera un nuevo ciclo revolucionario en Europa. Todas las

Además, se incluyen dos disposiciones transitorias, la primera de las cuales señala que la Ley que, en virtud de lo establecido en la Constitución, se elabore para elegir la persona del Rey, se incorporará al texto constitucional. La segunda transitoria señala que hasta que se promulgue la Ley Orgánica de los Tribunales, se autoriza al Gobierno para que dicte las medidas pertinentes en el orden judicial, especialmente en lo que atañe al nombramiento de jueces y magistrados. 
potencias europeas son conscientes de la necesidad de "fijar" y estabilizar la revolución. Para ello nada mejor que un texto constitucional rígido, que en su condición de norma fundamental del Estado, alejara cualquier posibilidad desestabilizadora.

Europa, tanto políticamente - tenía que evitar a toda costa que España se transformara en un ejemplo a seguir por otros paisescomo económicamente - hay importantes inversiones extranjeras al amparo de la liberalidad de la legislación española al respecto-; tenia que "enfriar" y controlar los entusiasmos revolucionarios que podían desencadenarse tras la expulsión de la Reina. El deseo de seguir de cerca este proceso que se abría tras la proclama de Cádiz, explica el rápido reconocimiento diplomático de todas las potencias del mundo, con la salvedad de Inglaterra y el Santo Padre. Pocas veces en la historia española la interrelación con Europa ha sido más evidente. La componente europea de lo español y la española respecto del continente se van a hacer muy presentes. Recuérdese, a título de ejemplo, el famoso telegrama de EMS y la excusa española para la declaración de guerra de Prusia a Francia.

La Constitución se presentaba como la «fachada de respetabilidad" del nuevo régimen tanto ante las fuerzas sociales que la habían hecho posible, como ante la Comunidad Internacional. Como dice Friedrich, la Constitución adquiere así un extraordinario valor simbólico.

La función ideológica hace de este texto un brillante exponente de las ideas rectoras que animan a los protagonistas de la revolución. Es un texto de gran altura que recoge las ideas políticas del grupo instalado en el poder. Aquí conviene hacer alguna matización. Salvo en el tema de la forma de gobierno, el resto de los principios que la Constitución contempla son asumidos por las fuerzas políticas mayoritarias. La extensa declaración de derechos que incluye es igualmente aceptada por la mayoría gubernamental o la minoría republicana. Sólo los tradicionalistas van a presentar enmiendas restrictivas en este terreno, especialmente en el tema de la libertad religiosa y de cultos. El resto de las fuerzas políticas en todo caso pugnaran por la ampliación de los derechos y libertades reconocidos en la Constitución. Por lo tanto, en el único aspecto que la Ley Fundamental no está consensuada, utilizando una terminología actual pero que ya salió a relucir en el debate constituyente, es el de la forma de Gobierno. "Cuestión batallona» que daría lugar a la violación "formal» de la Constitución otro 11 de febrero de 1873, concretamente del art. 47, que prohibía a las Cámaras la sesión conjunta, y del art. 74 , punto $7 .^{\circ}$ que exigía una ley especial de abdicación de la Corona. 
Por lo que respecta a la función organizativa, el texto del 69 cumple sobradamente los contenidos que señalara el profesor Pérez Serrano, «incluyendo el conjunto de reglas para el establecimiento y función de los diferentes poderes y autoridades, así como el reparto de competencias ${ }^{146}$. El texto establece la división de poderes o distribución funcional del poder, la forma de aplicación de este principio y naturalmente el tema de la forma de gobierno, es decir el modelo de la Jefatura del Estado.

Por medio de la llamada función política se intenta contestar a las preguntas básicas de la convivencia política, es decir ¿quién manda?, ¿por qué manda? y ¿cómo manda? Son las grandes cuestiones fronterizas entre el Derecho y la Política. Aquí entra en juego la concepción utilitarista de las constituciones, señalada especialmente por Loewenstein al asignarles como función principal ser un instrumento de limitación del poder ${ }^{147}$.

Ello por dos cuestiones fundamentales. Primera, la dificultad demostrada por la historia, de que el poder se autolimite. Segunda, por el carácter axiomático del mal citado epigrama de Lord Acton: «EI poder tiende a corromper y el poder absoluto tiende a corromperse absolutamente». Es necesaria la limitación del poder para evitar lo que Gerard Ritter llama los "efectos demoníacos» del mismo. La contestación a las tres preguntas básicas que incluye la función política, en el contexto de 1869, nos lleva a la siguiente respuesta. El quién manda deriva hacia el reconocimiento explicito de la soberanía nacional. Pero la personificación de esa soberanía va a recaer en un bloque compacto en el que se mezclan militares triunfadores de Cádiz, con los que hay que contar porque representan a la única institución que podía eliminar la dinastía, y un grupo de burgueses desencantados con la política económica de los últimos gobiernos de Isabel II, coronados todos ellos por la aureola de los llamados "demócratas de cátedra". La

146 Tratado de Derecho Político, Madrid, 1976.

147 «Rara vez, por no decir nunca, ha ejercido el hombre un poder limitado, con moderación y comedimiento. El poder lleva en sí mismo un estigma y sólo los santos entre los detentadores del poder. - ¿y dónde se pueden encontrar? serían capaces de resistir la tentación de abusar del poder. En nuestra exposición - continúa - ha sido hasta ahora usado el concepto poder para designar un ele. mento objetivo sin ninguna cualificación ética; sin embargo el poder incontrolado es por su misma naturaleza malo. El poder encierra en si mismo la semilla de su propia degeneración. Esto quiere decir que cuando no está limitado, el poder se transforma en tiranía y arbitrario despotismon. Véase su obra Teoría de la Constitución, págs. 28-29. 
segunda pregunta - el por qué mandan - tiene por primera vez en la historia española una respuesta plenamente satisfactoria. Mandan los que mandan porque cuentan con la legitimidad de su elección popular. Frente a los 16.000 electores del Estatuto Real, la Constitución de la Gloriosa ha sido elaborada por los representantes legítimos de más de 3 millones de electores. El cambio es substancial. El establecimiento del sufragio universal masculino en esta época es una auténtica avanzadilla democrática y un título de orgullo para España frente al resto de los países europeos. La tercera pregunta nos conduce directamente a lo que Jiménez de Parga llama "la verdad política de un régimen", es decir si estamos ante un sistema democrático o autocrático. Pues bien, con todas la imperfecciones - perfectamente reflejadas en las discusiones de actas-, con la actuación no siempre ejemplar del Ministerio de la Gobernación, etc., etc., de todo lo cual hemos dejado constancia en páginas anteriores, hay que afirmar que la Constitución de 1869 reunía todos los requisitos para declararse plenamente democrática. El régimen de libertad de prensa, la declaración extensiva de los derechos "inalienables" y para muchos incluso "ilegislables", la existencia de una opinión pública muy sensibilizada, al menos en sus cuadros medios, etc, hacia posible el control del poder político, en una medida como hasta entonces no se había dado en nuestra patria.

\section{LA REALIDAD DEL PODER}

El análisis de la llamada función política nos sirve de introducción al último epígrafe. Dónde estaba el poder y quién lo ejercía. Tuñón ha escrito sobre el llamado "problema del poder en el sexenio"148, para terminar afirmando que lo grave de la situación es que como proceso revolucionario fue incapaz de crear un "bloque social de poder" para afrontar las nuevas circunstancias que se avecinaban. Jutglar veía en el sexenio, desde el punto de vista de lo que llama «la fenomenología social de la revolución", un magnífico "banco de pruebas" o una especie de "laboratorio de ensayo" para experimentar nuevos modelos de poder y nuevas posibilidades de convivencia. Para ello la Constitución tendria que ser el punto de coincidencia de los sectores sociales que la habían hecho posible. Pero resulta que esos sectores, como se ha indicado más arriba, son los mismos que han protagonizado en mayor

148 Véase su colaboración en la obra colectiva La Revolución de 1868, dirigida por LIDA Y ZAVALA. 
o menor medida la vida política española en las décadas precedentes. De ahí la ironía de algunos intelectuales españoles cuando se preguntaban sobre el sentido de la revolución. Joaquín Costa, posiblemente el más benigno en su crítica, la deja reducida a una simple noticia en la Gaceta Oficial.

El primer problema en orden al poder durante la revolución está en el carácter dual con que se presenta. De entrada hay dos «bloques de poder" perfectamente diferenciados. De un lado, las Juntas. De otro, los generales sublevados. Movimiento popular de claro contenido democrático versus elites de composición escogida, como es consustancial con ellas y en muchos casos aristocrática desde el punto de vista social. Frente a ambas realidades de poder emergente, un poder en plena decadencia con una Reina que forma parte de lo que llama Galdós la "Dinastía fugitiva" y una clase política que adopta las precauciones necesarias para incorporarse a las nuevas expectativas que se abren.

El juntismo es un fenómeno sociopolítico de gran tradición en España, consistente en la toma del poder por elementos populares en momentos de crisis o descomposición política. Generalmente el pueblo va a ocupar los espacios políticos que por cobardía o imposibilidad dejaban abandonados las clases dirigentes. Sucedió en la invasión francesa, cuando la familia real marcha a Francia y se repite en 1868 coincidiendo con otra salida al país vecino de doña Isabel de Borbón, familia y camarilla.

Las Juntas fueron muchas $y$ todas ellas contaban con su propia organización interna, sus líderes naturales y un programa de actuación. En cuanto al programa, casi todas las Juntas que surgen en España, copian el de la Junta de Sevilla, obra del profesor republicano don Federico Rubio, o el de la de Cádiz del también político republicano Sr. Benot. Curiosamente ni una sola de estas juntas populares había sido elegida por el pueblo, como pone de relieve Estévanez ${ }^{149}$, lo que no pone en duda su legitimidad de ejercicio, ya que eran implícita y explícitamente aceptadas por todos. En las grandes ciudades tenían un carácter de comuna de barrio y asumían la administración de competencias hasta entonces llevadas a cabo por los ayuntamientos. Podía darse el caso de una duplicidad de Juntas, bien de forma simultánea o sucesiva: este es el caso de Madrid, que llega a tener hasta tres Jun-

149 «Ni una sola de las Juntas Revolucionarias habia sido elegida por la plebe", op. cit., pág. 160. 
tas. Valeriano Bozal tiene una monografía sobre el tema con el sugerente título de "Las Juntas Revolucionarias. Manifiestos y proclamas de 1868", aparecido precisamente en el centenario de la revolución. Detrás de ellas suele estar muy presente el liderazgo natural que se ejerce en clubs políticos o incluso en las redacciones de los órganos de prensa más combativos. En Madrid tuvieron mucha influencia el Club Republicano de la calle de La Yedra, el del Casino en la calle Mayor o el del Congreso en la calle del Cabo. Las Juntas elevan a la opinión pública sus propios Manifiestos, donde hacen un análisis de la situación del país y exponen sus posibles soluciones. Sevilla es la pionera en esta actuación seguida muy pronto por Málaga y luego todas las demás. La labor de las Juntas es pues importante, máxime si se tiene en cuenta que evitan el vacío de poder. Por otra parte los mecanismos de acción política que suelen practicar entran dentro de la más pura ortodoxia. Sólo algunos sectores controlados por los incipientes anarquistas son partidarios de la acción directa. En las demás, y como ha puesto de relieve Valeriano Bozal, lo normal es que abunden los planteamientos de carácter ético y dentro de lo que Jover llama "el espíritu de los setenta». Las Juntas son el reino de la Utopía, en muchos aspectos, y entre sus sueños utópicos están los más altos contenidos de la revolución: la abolición de las quintas, la proclamación de la república y el mito de la federal. Como escribe Jover: "La utopía de una democracia universalista que puede corregir los excesos de un nacionalismo autoritario". Este componente utópico de las Juntas es lo que hará de la Revolución española de 1868 un modelo a imitar y objeto de admiración para los sectores populares europeos. De ahí el miedo de contagio que tenían los gobiernos y al que me he referido. El interés que despierta el fenómeno español es tan grande que, como ha destacado Victoria López Cordón, habrá que esperar a la guerra civil de 1936 para que nuestra Patria levante el mismo interés informativo en la prensa mundial. Especialmente en Italia y Portugal, el septiembre español se presenta como el anuncio de una nueva era para la humanidad. Pero sin embargo las Juntas y todo lo que representan no son bien vistas por los militares -el otro bloque de poder-. Dice Estévanez que el programa juntero "era considerado utópico por los unionistas y absurdo por los progresistas" 150 . Ello explica que intentaran descle el primer momento acabar con ellas.

De entre todas las Juntas Revolucionarias, Madrid, desde el primer momento, se configura como la sede de la nueva soberanía 
nacional tras la marcha de la Reina. Y Madrid confiere el poder a Serrano el 4 de octubre de 1868. El teórico héroe de Alcolea no duda en aceptarlo y da paso a un gobierno provisional. He aquí un detalle significativo. Hay una transferencia de legitimidad política de las Juntas a los militares. Conviene señalar sobre la Junta de Madrid, que toma estas decisiones sin contar con las demás, que Barcelona reclamaría y denunciaría por medio de sus representantes en las Constituyentes este abuso de competencias de su homónima madrileña. Figueras llega a decir en las Cortes que uel gobierno provisional es un gobierno dictatorial, ilegítimo, ilegal, que ha usurpado la soberanía de la Nación en beneficio de un determinado partido", para más adelante añadir que el acatamiento de las Juntas fue como consecuencia de la presión ejercida por el Gobierno que llegó a poner las cosas de tal modo que incluso podría haber estallado una guerra civil ${ }^{151}$. También a destacar lo que supone de reconocimiento del poder de las Juntas, cuando se acepta el traspaso de poderes que le hacen al Ejército. La primera labor del nuevo poder establecido será poner en marcha el proceso de disolución de las mismas. Aquí se observa la habilidad de Prim que confía esta tarea a sus compañeros de pronunciamiento. Como señala Carr, «el gobierno provisional de Serrano tuvo que emprender la tarea tradicional de todos los gobiernos salidos de la combinación de un pronunciamiento con una revuelta popular: la sustitución de un sistema dualista, en el que los asuntos locales estaban en manos de las Juntas revolucionarias y el poder en manos de un gobierno central» 152 .

Naturalmente esta dualidad plantea problemas. El gobierno provisional hace suyas algunas de las propuestas de las juntas y logra convencer a sus dirigentes de la conveniencia de su disolución. Aquí juega un papel fundamental el General Prim. El día 19 de octubre convence a la Junta de Madrid para que se autodisuelva. Haciendo gala del pragmatismo que le caracteriza mete en nómina a todos sus dirigentes. Resuelve un problema político utilizando recetas económicas. Viejo y rentable procedimiento el dar un puesto al sol del presupuesto nacional para resolver litigios de poder. Un personaje de Galdós habla de "los gandules presupuestivoros". Curiosamente los Voluntarios de la Libertad - menos políticos pero más pueblo, como ha señalado Melchor Fernández Almagro - se muestran insobornables y se resisten a disolverse ${ }^{153}$. El ejemplo de Madrid es seguido con más o

153 Op. cit., pág. 27. 
menos resistencias por las demás Juntas. La última en disolverse fue la de Teruel154.

Ha llegado la hora de que empiecen a manifestarse las disfunciones entre Junta y Gobierno. El divorcio se produce con motivo de la forma de gobierno, aunque no sólo eso. En el fondo está el dilema entre Revolución y Pronunciamiento. Las Juntas creían en la Revolución. Esperaban un cambio en las personas, en las instituciones y en sus condiciones de vida. Creian firmemente que sus creencias en un mundo mejor podrian empezar a realizarse. Esperaban transformaciones económicas y sociales que hicieran su existencia más llevadera y justificara la revolución ${ }^{155}$. El Gobierno y el bloque de poder que le apoya - monárquicos sin Rey y burguesía financiera - buscan cambios políticos que le permitan la mejor defensa de sus intereses económicos, por lo que en la línea del pensamiento constitucional de la época, cerrarán el paso a cualquier función transformadora en el texto constitucional. De ahí la frustración. El pueblo descontento sueña con una república que cuando llegue llevará dentro de sí el estigma de su fracaso, como señala Lacomba.

Esta dualidad inicial de focos de poder explica una de las grandes cuestiones de la Gloriosa y sobre la que casi todos los historiadores del Derecho y la Política se han manifestado en nuestra Patria. La Gloriosa como Revolución o como Pronunciamiento. La respuesta desde este planteamiento no ofrece duda. Revolución para unos. Pronunciamiento para llegar al Poder para otros. En las Constituyentes, Figueras recordaría más de una vez a la mayoría que se habían limitado a llevar a cabo una pronunciamiento más en la larga historia de España. A partir de aquí, los "militares revolucionarios" de Cádiz, apoyados por los civiles que forman parte de su gobierno, tendrán que

154 En diciembre, y faltos ya del control que en cierto modo ejercían las Juntas, empiezan los movimientos políticos y sociales por la geografía española. Movimientos que reflejan en gran parte la decepción que se vive tras la frustrada revolución. Del 5 al 8 de diciembre de 1868, la ciudad de Cádiz se levanta al grito de "República Federal o muerte», dirigidos por Fermín Salvoechea (esta acción le costaría su escaño de diputado en las Constituyentes). Málaga se suma al movimiento insurreccional el día 1 de enero del año siguiente. $Y$ a continuación el Puerto de Santa Maria, Béjar, Badajoz, Tarragona, Sevilla, Orense, Gandía, etc. El Diario de Sesiones de las Constituyentes ofrece un amplio muestrario de este descontento popular.

155 En el fondo, y sin saberlo, participaban del esquema revolucionario puro que diseñaría muchos años después el sociólogo BURHAM, que define la revolución como un cambio de creencias, de personas e instituciones. 
transformarse en "conservadores" de la revolución. En este sentido hay que entender la Circular del 4 de noviembre de 1868, firmada por Prim como ministro de la Guerra, prohibiendo a los militares en activo el derecho de asociación política y el tomar parte en manifestaciones y actos partidistas contra el Gobierno. El día 12 de noviembre Topete hace lo mismo con los miembros de la Armada. Sagasta, con fecha 29 de noviembre, dirige una circular a los Gobernadores Civiles estimulándoles para que mantengan el orden público a todo trance y su compañero de gabinete, el Ministro de Justicia Romero Ortiz en la misma fecha da instrucciones al Ministerio Fiscal, excitando su celo para que no queden impunes los actos delictivos que puedan empañar la imagen de la Revolución. Son las transformaciones que opera la realidad del poder en los antiguos y conspicuos conspiradores. En el fondo casi todo seguía igual. El poder estaba donde siempre y a lo sumo habían cambiado algunas personas de las que lo ejercían, ni siquiera todos. Por parte de la ciudadanía española habían aprendido una lección amarga pero cierta: sus intereses no coincidían en absoluto con los de las clases dirigentes. Sería la última vez que confiarían en ellos. Esta toma de conciencia dejaría su impronta para el futuro y marcaría algunos de los acontecimientos políticos más significativos de finales del XIX y el siglo XX. La Revolución se había quedado sin contenidos. Se habían alcanzado algunos objetivos políticos de carácter liberal en ocasiones muy acentuado, ciertamente importantes, pero los de contenido ético social, como señala Aranguren, habían caído bajo "la moralina" de la revolución ${ }^{156}$. Cuando por parte del Gobierno y las fuerzas sociales que le respaldan se pretenda justificar el fracaso político de la Septembrina, se utilizará como "coartada política" la consabida inmadurez de la sociedad española de su tiempo, la falta de cimientos $^{157}$ o la carencia de una mesocracia que pudiera asumir las conquistas de la revolución y su traducción en una constitución socialmente aún más avanzada ${ }^{158}$.

\section{CONCLUSIONES}

Como resumen de todo lo expuesto se puede señalar la necesidad de entender la Constitución como un hecho histórico que forma

156 Moral y Sociedad, pág. 151.

157 Ésta es la tesis de Victoria LÓPEZ CORdón. Véase Historia..., pág. 484.

158 Tal es la tesis de DONEZA, op. cit., pág. 53. 
parte de un conjunto, que a su vez actúa dentro de una realidad histórico-política determinada.

Este hecho histórico es el resultado de un acontecimiento previo que es la revolución. Ambos están interconectados y se proyectan sobre una realidad espacio temporal en la que está en vigor una determinada cultura política.

Esta cultura política refleja la realidad no sólo histórica, sino también social, cultural y económica del país. De ahí que para su cabal comprensión tengamos que conocer las mentalidades de la época reflejadas en su literatura, sus creaciones artísticas y de modo especial su prensa.

La acción conjunta de todos estos parámetros nos permitirá ver el texto de la Constitución como parte de una interpretación integral de la sociedad española de su tiempo.

Hay que destacar como primera conclusión que de todos los hechos históricos que se dan dentro de la estructura del sexenio, el verdaderamente relevante es la revolución.

En segundo lugar destacar el carácter puramente instrumental que las fuerzas sociales instaladas en el poder dan al texto constitucional. En muchos casos se observa en el seguimiento del debate que sólo se dan curso a las peticiones que no afectan al fondo último de la situación. Olvido total de la supresión de quintas, de la sustitución de los consumos y por supuesto del tema de la forma de gobierno. La Constitución es un mero instrumento de las ideas políticas y los intereses del grupo instalado en el poder.

En tercer lugar, se deduce que el fracaso de la fase septembrina estaba cantado. La República tenia que llegar forzosamente. También tenía que fracasar. La conclusión resultante es que la fase republicana es el parentésis necesario para la Restauración.

La habilidad e inteligencia política de los hombres que dirigen primero la revolución y luego la acción política subsiguiente está fuera de toda duda. La ingenuidad popular también. Lo primero se deduce del análisis de la acción de gobierno. Lo segundo de la lectura de la obra de Galdós, principalmente. A lo largo de un censo de más de $\mathbf{8 . 0 0 0}$ personajes que aparecen en su obra literaria hay una extraña coincidencia sobre la falta de malicia de las clases populares a la hora de participar en los principales eventos políticos.

La existencia de un continuum entre el constitucionalismo anterior y el posterior a la.constitución de la Gloriosa. En mi opinión, vale 
igualmente la pena proyectar esta influencia hacia adelante. Destacar la conexión entre la Constitución del 69 y el mundo de ideas políticas que se ponen en circulación en los años veinte de este siglo, algunas de las cuales verían su plasmación el la Constitución de 1931. Por lo tanto puede afirmarse como conclusión que la constitución de 1869 es el puente político ideológico necesario entre la Nonata y la republicana de 1931.

La frustración de los objetivos de la revolución mantiene latentes las utopías del 68. De esta forma el recuerdo de la revolución va a llenar de contenido utópico los sueños de muchas generaciones de españoles para los años sucesivos. La lectura de la literatura y la novela social de la época lo ponen de manifiesto.

En los debates parlamentarios sorprende por un lado la altura de los discursos que se pronuncian, la amplia cultura de que se hace gala y el pesimismo convencido y resignado que se desprende de la minoría republicana que ve una y otra vez bloqueados sus intentos en pro de la inclusión de la forma republicana en el texto constitucional. Este pesimismo, en mi opinión, va a estar presente en la melancolía que acompaña a un sector de la inteligencia española en la crisis finisecular e incluso se puede hacer presente en la Generación de 1914. Desde los Regeneracionistas, con Joaquín Costa a la cabeza, hasta los nietos del 68 con Ortega y Azaña, el recuerdo del 68 va a servir en muchos casos de incentivo y estimulo.

Del análisis del texto y por lo que a las llamadas funciones se refiere se deduce como realidad incontestable y por supuesto conclusión de la misma la inexistencia de la llamada función transformadora. Ello tendrá importantísimas consecuencias en el orden socio político. Las clases que han sido carne de la revolución en las barricadas callejeras o en los fusilamientos subsiguientes a la asonada de San Gil quedan absolutamente desencantadas de la revolución. Frente al liberalismo democrático del texto, la falta de motivaciones sociales conducirá inevitablemente a la decepción ciudadana.

En cuanto al sentido y alcance de la revolución, la conclusión pertinente es que estamos ante el último intento de la burguesia para tomar el poder con todas sus consecuencias. La próxima vez será ya en 1923, en circunstancias muy similares, pero a diferencia de 1868, encontrará en la Corona su mejor aliado. 1868 es la unión de la burguesía, el ejército y los demócratas de cátedra. En 1923 el bloque de poder lo integran la burguesía, el ejército y la corona. La «inteligencia" no sólo queda al margen, sino que será abiertamente beligerante. Por eso en 1868 todo queda al final en un cambio de dinastía. En 
1931 - consecuencia directa de 1923 - se dará paso a un cambio de régimen. En este sentido, la II República Española - no la primeraserá la culminación del proceso de cambio político que se inicia en Cádiz en 1868 y termina en el Pacto de San Sebastián de 1930.

La crisis que acompaña a todo proceso revolucionario es una realidad incontestable. Crisis múltiple. Crisis entendida no sólo como anticipo o causa de la revolución sino también como corolario de la misma. La conclusión es que si la revolución se abre con una crisis, se cierra en falso con otra. De ahí la frustración de la I República.

La crisis hay que entenderla desde todos los puntos de vista. Política, tanto en el nivel del sistema político como de la clase política usufructuaria del mismo. En esta crisis conviven dos generaciones distintas. De un lado los políticos de la vieja escuela que ya han participado desde el gobierno o la oposición en anteriores momentos constitucionales. De otra asoma una nueva generación que estrena sus armas en 1869 y alcanzará su plenitud política en la restauración canovista sin solución de continuidad.

A destacar la importancia de la crisis ideológica y la conclusión subsiguiente: la falta de originalidad del pensamiento político español de la época. En el terreno ideológico se esta creando el clima de «calma chicha" que Ortega señala como definitorio de la Constitución de 1876 y la Restauración Canovista. En este sentido hay que poner de relieve cómo la "moralina" superficial sustituye los grandes y profundos principios que habían insuflado la revolución.

El análisis de la realidad del poder derivado de Cádiz lleva a la conclusión de la inexistencia de una auténtica voluntad de cambio politico por parte de los protagonistas oficiales de la Revolución. Igualmente nos permite diferenciar entre dos realidades distintas que coinciden en Cádiz y empiezan a disociarse a partir de la escaramuza de Alcolea y se diferencian abiertamente tras la apertura de las Constituyentes. Me refiero a la llamada revolución dual. En el capítulo de las conclusiones puede deducirse que hubo dos movimientos distintos en cuanto a sus agentes y procedimientos, aunque coincidentes en sus objetivos iniciales. Me refiero a la diferenciación entre revolución y pronunciamiento. La primera entra en la concepción popular. El segundo está inspirado y protagonizado por las clases superiores del ejército y la burguesía financiera. 